\title{
Holding Standards for RANDsome: A Remedial Perspective on RAND Licensing Commitments
}

\author{
Layne S. Keele*
}

\section{INTRODUCTION}

A patent derives value from its owner's ability to exclude others from practicing the patent. ${ }^{1}$ If others could freely implement the patented technology without repercussion, the patent would be worthless. Industry standards, on the other hand, are valuable for precisely the opposite reason - they are valuable only if industry participants adopt them, and they gain value as they become more widely used. ${ }^{2}$ Because of these opposing sources of value, a natural tension arises when patented technology is incorporated into an industry standard. The standard-setting organization wants broad implementation of the standard, but patent rights can interfere with implementation.

A patent holder who owns a standard-essential patent (that is, a patent that covers some portion of an industry standard) wields a lot of power. The patent holder can command exorbitant licensing fees-fees far exceeding market value - because anyone who wants to comply with the standard will have to pay. This phenomenon is known as "patent holdup."3

To ameliorate patent holdup concerns, most standards-setting organizations, or SSOs, ${ }^{4}$ attempt to procure patentees' licensing

\footnotetext{
* Associate Professor of Law, Faulkner University's Thomas Goode Jones School of Law. The author would like to thank everyone who offered helpful comments and critiques at the Remedies roundtable of the 2014 annual meeting of the Southeastern Association of Law Schools and, in particular, Professors Caprice Roberts and Mike Allen for organizing the discussion. In addition, the author thanks the talented editors at the UNIVERSITY OF KANSAS LAW REVIEW for their editorial improvements.

1. Alan C. Marco \& Saurabh Vishnubhakat, Certain Patents, 16 YALE J.L. \& TECH. 103, 104 (2013-14).

2. See Janice M. Mueller, Patenting Industry Standards, 34 J. Marshall L. ReV. 897, 905 (2001).

3. Mark A. Lemley, Ten Things To Do About Patent Holdup of Standards (And One Not To), 48 B.C. L. REV. 149, 151-52 (2007).

4. SSOs are also sometimes referred to as standards-developing organizations, or SDOs. See Thomas F. Cotter, Patent Holdup, Patent Remedies, and Antitrust Responses, 34 J. CORP. L. 1151, 1207 n.13 (2009).
} 
commitments before adopting standards. Specifically, most SSOs insist that their members agree in advance to license any standard-essential patents on reasonable and non-discriminatory (RAND) terms. ${ }^{5}$ But this is a vague standard, and, predictably, patentees often disagree with implementers about whether offered license rates are in fact reasonable and non-discriminatory. ${ }^{6}$ Recently, these disagreements have prompted a spate of litigation, leaving courts to grapple with the task of determining the substantive obligations entailed in a patentee's RAND commitment. ${ }^{7}$

This Article examines the remedies available in RAND disputes through the lens of various remedial interests-specifically, the restorative, coercive, and protective interests. In particular, it discusses the availability of injunctive relief and enhanced damages as remedies for an implementer's infringement of RAND-encumbered patents. In the course of this discussion, the Article also evaluates the rightful position of the parties involved and the impact that various remedies will have on the parties' incentives toward or away from socially optimal behavior. Ultimately, the Article suggests - contrary to the arguments raised by other scholars - that courts can employ traditional remedial doctrines to resolve concerns about RAND-encumbered patents.

Part I introduces the basic concepts behind the RAND commitment and reviews the terms typically found in such commitments. Part II examines various competing views regarding the contours of RAND commitments, including the implied license view, the waiver view, and, most importantly for purposes of this Article, the contract view. This Part also addresses how the remedies available to patentees for infringement of RAND-encumbered patents shape the RAND

5. RAND terms are sometimes also referred to by some SSOs as fair, reasonable, and nondiscriminatory terms, or FRAND terms. See generally Steven M. Amundson, Recent Decisions Provide Some Clarity on How Courts and Government Agencies Will Likely Resolve Issues Involving Standard-Essential Patents, 13 CHI.-Kent J. InTELL. PROP. 91, 93 (2013).

6. See Press Release, Department of Justice, Statement of the Department of Justice's Antitrust Division on Its Decision to Close Its Investigations of Google Inc.'s Acquisition of Motorola Mobility Holdings Inc. and the Acquisitions of Certain Patents by Apple Inc., Microsoft Corp. and Research in Motion Ltd. (Feb. 13, 2012), http://www.justice.gov/opa/pr/2012/February/12-at-210.html ("SSO F/RAND requirements have not prevented significant disputes from arising in connection with the licensing of SEPs, including actions by patent holders seeking injunctive or exclusionary relief that could alter competitive market outcomes.").

7. E.g., Ericsson, Inc. v. D-Link Sys., Inc., 773 F.3d 1201, 1231-32 (Fed. Cir. 2014); Apple Inc. v. Motorola, Inc., 757 F.3d 1286, 1332 (Fed. Cir. 2014), overruled by Williamson v. Citrix Online, LLC, 792 F.3d 1339 (Fed. Cir. 2015); In re Innovatio IP Ventures, LLC Patent Litig., No. 11 C 9308, 2013 WL 5593609, at*11 (N.D. Ill. Oct. 3, 2013); Realtek Semiconductor Corp. v. LSI Corp., 946 F. Supp. 2d 998, 1007 (N.D. Cal. 2013); Microsoft Corp. v. Motorola, Inc., No. C101823JLR, 2013 WL 2111217, at*10-11 (W.D. Wash. Apr. 25, 2013). 
commitment, and it analogizes RAND commitments to open-price contracts under Article 2 of the Uniform Commercial Code. Part III provides a suggested remedial structure for cases involving RANDencumbered patents, discussing whether and when injunctive relief and enhanced damages should be available to the patentee. Finally, Part IV surveys the methodology for judicial determination of a RAND licensing rate, including a suggested framework.

\section{A. Background of the RAND Commitment}

Standards are crucial in a connected society. Consider a world without standards. One brand of wireless device might work with some routers, but it might be incompatible with others. ${ }^{8}$ A person's cell phone might work at home but not at work, or they may be able to call only individuals with the same brand of phone. Standards assure compatibility across a broad spectrum of devices and manufacturers. The United States is home to approximately 50,000 private-sector standards developed by more than 600 organizations. ${ }^{9}$

Standards can incorporate technology subject to hundreds or even thousands of patents, ${ }^{10}$ and a patentee holding one of these "standardessential patents," or SEPs, stands to gain enormous leverage in licensing negotiations once its patent is incorporated into a standard. The patentee could prevent competitors from implementing the standard even if its patent covered only a very minor part of the standard. Consequently, the patentee could command supracompetitive licensing fees for its patent, based not on the value of the patented technology, but on the value of the standard as a whole. In other words, the patentee can engage in "patent holdup." $" 1$

The potential for patent holdup is a function of the value that

8. This situation arose, for example, after the FCC's decision to open wireless communication in certain unlicensed bands. As Judge Robart put it, " $[\mathrm{t}]$ he proprietary solutions were expensive and forced users to buy all networking components from the same manufacturer." Microsoft, 2013 WL 2111217 , at $* 49$.

9. Overview of the U.S. Standardization System, AM. NAT'L STANDARDS InST. (2013), http://www.standardsportal.org/usa_en/standards_system.aspx.

10. See, e.g., Innovatio, 2013 WL 5593609, at *43 (3,000 claimed standard-essential patents in 802.11 Wi-Fi standard); Microsoft, 2013 WL 2111217, at *86 (at least 2,500 patents essential to the H.264 standard); Lemley, supra note 3, at 152 (describing 6,000 claimed essential patents for 3G telecom in Europe).

11. Lemley, supra note 3, at 153-54; see also Jorge Contreras, Remarks at the Fed. Trade Comm'n Workshop on Intell. Prop. Rights and Standard Setting: Tools to Prevent Patent "Hold-Up", 26-27 (June 21, 2011), http://www.ftc.gov/sites/default/files/documents/public_events/toolsprevent-patent-hold-ip-rights-standard-setting/transcript.pdf [hereinafter "FTC"]. 
inclusion in a standard adds to the patentee's right to exclude. ${ }^{12}$ In a normal negotiation for a patent license, a prospective licensee will never pay more than the incremental value of the patented technology over competing technology (that is, the value over the next-best alternative) plus any cost of licensing the competing technology. For example, if a patented egg-washing machine could wash 8000 eggs a month, and it would cost $\$ 1000$ to wash those 8000 eggs by hand (the next best alternative), then the licensee would pay no more than $\$ 1000$ to license the machine. ${ }^{13}$ But, when a patent has been incorporated into a standard, adopting competing technology may no longer be a viable option for industry participants, both because the alternative technology would not be compatible with the standard and because the would-be standard implementer likely will have already invested heavily in standard compliance. Consequently, a patentee wielding the threat of an injunction could demand exorbitant licensing fees. ${ }^{14}$ The RAND commitment alleviates this problem by assuring potential implementers that holders of SEPs will not engage in patent holdup. ${ }^{15}$

Most SSOs require members to agree that they will license standardessential patents ("SEPs") on RAND terms. ${ }^{16}$ The actual terms of RAND obligations vary from SSO to SSO,${ }^{17}$ but they usually entail the patentee's assurances that it will make licenses "available" to applicants on RAND terms, ${ }^{18}$ that it is "prepared" to grant licenses on RAND terms, ${ }^{19}$ or that it is willing to negotiate licenses on RAND terms. ${ }^{20}$ The

\footnotetext{
12. See generally Ericsson, 773 F.3d at 1232
}

13. In fact, it would pay less if there were any costs associated with maintaining the machine or lost goodwill in having to lay off employees.

14. See Broadcom Corp. v. Qualcomm Inc., 501 F.3d 297, 310-11 (3d Cir. 2007); Realtek Semiconductor Corp. v. LSI Corp., 946 F. Supp. 2d 998, 1008 (N.D. Cal. 2013) (seeking an injunction "is a clear attempt to gain leverage in future licensing negotiations"); Lemley, supra note 3 , at $153-54$.

15. Ericsson, 773 F.3d at 1209; In re Innovatio IP Ventures, LLC Patent Litig., 956 F. Supp. 2d 925, 932 (N.D. Ill. 2013); Microsoft, 2013 WL 2111217, at *10-11.

16. Letter from David Heiner, Vice President and Deputy Gen. Counsel, Microsoft Corp., \& Amy Marasco, Gen. Manager, Standards Strategy and Policy, Microsoft Corp., to Fed. Trade Comm'n, at $\quad 5 \quad$ (June https://www.ftc.gov/sites/default/files/documents/public_comments/request-comments-andannouncement-workshop-standard-setting-issues-project-no.p111204-00009\%C2\%A0/0000960523.pdf.

17. Ericsson, 773 F.3d at 1231.

18. See id. (describing the policies of IEEE); Realtek Semiconductor Corp. v. LSI Corp., No. C-12-03451 RMW, 2012 WL 4845628, at*1 (N.D. Cal. Oct. 10, 2012) (IEEE bylaws sought Letters of Assurance that patentee "is prepared to grant a license to an unrestricted number of applicants on a worldwide, non-discriminatory basis and on reasonable terms and conditions") (citation omitted).

19. See, e.g., European Telecommunications Standards Institute, ETSI RULES OF PROCEDURE, ANNEX 6: ETSI INTEllectual PROPERTy Rights POLICY § 6.1 (2014).

20. David L. Newman, "Going Once... Going Twice... Licensed Under the Most 
Joint Electron Device Engineering Council (JEDEC) requires its participants to agree to "offer to license on RAND terms to all Potential Licensees" any patent having standard-essential claims. ${ }^{21}$

\section{COMPETING VIEWS ON THE CONTENT OF A RAND COMMITMENT}

The language of the RAND commitment is familiar to those who have studied the regulatory tariff regime of public utilities and common carriers, which for many years were "required to offer their customers service under rates and practices that were just, reasonable, and nondiscriminatory." 22 To achieve this end, federal and state legislatures created commissions and required the carriers to file public tariffs setting forth their rates. ${ }^{23}$ Thus, the rates were fixed, and any deviation from the filed rates was prohibited. ${ }^{24}$

The parallel to the regulatory tariff model would be for SSOs to require patentees to commit to license all adopters at fixed or predetermined rates (in essence, to post their prices). But SSOs have resisted such a model out of dual concerns about antitrust liability and the alienation of some members. ${ }^{25}$ Thus, the RAND commitments required by SSOs have remained intentionally vague, and most SSOs have been content to require the RAND commitment ex ante and allow patentees and implementers to work out the specific terms ex post. The "non-discriminatory" aspect of the RAND commitment has not engendered much debate, ${ }^{26}$ but the requirement that a patentee's licensing offers or negotiations be "reasonable" has been fodder for a growing number of lawsuits in recent years. ${ }^{27}$ Commentators have taken

Reasonable and Non-Discriminatory Bidding Terms!", 11 NW. J. TeCH. \& INTELL. PROP. 139, 141 (2013) (describing IPR policies of ITU).

21. See JeDEC Solid State Technology Association, JeDEC Policies Manual, JM21R $\S 8.2 .4$ (July 2015) ("Potential Licensees" is broadly defined: "All . . Committee Members and non-members."); Id. § 8.2.1.

22. Joseph D. Kearney \& Thomas W. Merrill, The Great Transformation of Regulated Industries Law, 98 COLUM. L. REv. 1323, 1330-31 (1998).

23. Id. at 1331 .

24. Id.

25. FTC, supra note 11, at 10 (remarks of Commissioner Edith Ramirez). At least two SSOs, however, encourage SEP patentees "to disclose the most restrictive licensing terms they would demand, including maximum royalty rates." Id.

26. In the regulatory environment, “'[n]ondiscriminatory' limits any 'unjust or unreasonable' discrimination based on persons, classes of persons, or localities." Luke J. Burton, The Preemptive Effect of Federal Communications Act \$\$ 201-02 Postdetariffing, 2013 U. CHI. LEGAL F. 563, 563 (2013) (citation omitted).

27. See, e.g., Ericsson, Inc. v. D-Link Sys., Inc., 773 F.3d 1201, 1231-32 (Fed. Cir. 2014); Apple Inc. v. Motorola, Inc., 757 F.3d 1286, 1332 (Fed. Cir. 2014), overruled by Williamson v. Citrix Online, LLC, 792 F.3d 1339 (Fed. Cir. 2015); In re Innovatio IP Ventures, LLC Patent Litig., 
several different views on the obligations and restrictions resulting from a RAND-commitment.

\section{A. Waiver and Implied License}

There are three important views that scholars and litigants have articulated regarding the substance of the RAND commitment: the waiver view, the implied license view, and the contract view. The waiver view suggests that the RAND commitment reflects an irrevocable waiver of the patentee's rights to pursue injunctive relief or enhanced damages for infringement of the patent. ${ }^{28}$ The implied license view posits that the RAND commitment is an implied license to all implementers, so that the patentee "has only a contractual claim for a royalty [against an infringing implementer], not a cause of action for patent infringement that might result in an injunction, treble damages, and attorneys' fees." 29

Certainly these views have conceptual appeal, not the least of which is the ease of implementation. Under these views, the patentee has no substantive obligation toward the implementer (such as to make a goodfaith offer), and the implementer has no substantive obligation toward the patentee (such as to avoid willful infringement). Thus, among other things, these views would eliminate contentious lawsuits about the patentee's breach of its RAND commitment. ${ }^{30}$ Under the waiver view, the patentee may sue the adopter at any time, but its remedy will be limited to the reasonable royalty at a RAND rate, regardless of the infringer's willfulness, and a prohibitory injunction will never be an option. ${ }^{31}$ Under the implied license view, the patentee merely has a contract claim for breach of the implied license at the RAND rate and,

No. 11 C 9308, 2013 WL 5593609, at*11 (N.D. Ill. Oct. 3, 2013); Realtek Semiconductor Corp. v. LSI Corp., 946 F. Supp. 2d 998, 1007 (N.D. Cal. 2013); Microsoft Corp. v. Motorola, Inc., No. C101823JLR, 2013 WL 2111217, at*10-11 (W.D. Wash. Apr. 25, 2013).

28. Doug Lichtman, Understanding the RAND Commitment, 47 Hous. L. REv. 1023, 1043 (2010); see also Letter from Vaishali Udupa, IP Litig. Counsel, Hewlett-Packard Co., to Lisa R. Barton, Acting Sec'y, U.S. Int'l Trade Comm'n, 15-16 (Dec. 3, 2012), http://www.essentialpatentblog.com/wp-content/uploads/sites/234/2013/01/Hewlett-Packard-PublicInterest-Comments-337-TA-794.pdf ("[S]ome contend that even if exclusion orders are an inappropriate remedy for enforcing standards-essential patents as a general matter, such orders remain appropriate when the infringer (1) refuses to agree to pay a standard-essential patentee's proposed reasonable royalty, (2) refuses to pay a court-ordered royalty, or (3) challenges the validity of the patent or argues non-infringement. None of these situations warrants an exclusion order.").

29. Mark A. Lemley, Intellectual Property Rights and Standard-Setting Organizations, 90 CAL. L. REV. 1889, 1925 (2002).

30. E.g., cases cited supra note 27.

31. Lichtman, supra note 28, at 1043. 
presumably, would have to pursue that claim periodically throughout the life of the patent. ${ }^{32}$

Despite their conceptual appeal, courts have not adopted either of these views. ${ }^{33}$ The waiver view is difficult to reconcile with the traditional waiver description of intentional relinquishment of a known right $^{34}$ - many SSO participants would be surprised to learn that they had relinquished rights to injunctive relief, as demonstrated by many amicus briefs in Apple v. Motorola that argued for the availability of injunctive relief. $^{35}$ Indeed, SSO participants' efforts to add waiver language into their SSO policies have been unsuccessful and have generally met with strong resistance. ${ }^{36}$ And some SDOs have explicitly rejected the view that a RAND commitment creates an implied license, ${ }^{37}$ which, as Professor Lemley recognized, would leave state courts to adjudicate claims of infringement and patent validity in the form of a contract claim. ${ }^{38}$ Perhaps more importantly, as explained below, ${ }^{39}$ these views

32. Lemley, supra note 29 , at $1925-26$.

33. See, e.g., Apple Inc. v. Motorola, Inc., 757 F.3d 1286, 1332 (Fed. Cir. 2014), overruled by Williamson v. Citrix Online, LLC, 792 F.3d 1339 (Fed. Cir. 2015); Microsoft Corp. v. Motorola, Inc., 963 F. Supp. 2d 1176, 1190 (W.D. Wash. 2013); see also Suzanne Michel, Bargaining for RAND Royalties in the Shadow of Patent Remedies Law, 77 ANTITRUST L.J. 889, 909 (2011) (discussing considerations of injunctive relief in the RAND context); but see In re Innovatio IP Ventures, LLC Patent Litig., 956 F. Supp. 2d 925, 936 (N.D. Ill. 2013) (opining in a related context that RAND is "comparable to the existence of a license, which is also a contractual commitment limiting the liability of a patent infringer").

34. Standard Indus., Inc. v. Tigrett Indus., Inc., 397 U.S. 586, 587 (1970). Of course, waivers need not always be intentional - modern waiver doctrine includes some unintentional waivers. See McKinney v. Allstate Ins. Co., Civ. No. 08-3769ADM/JSM, 2009 WL 1927818, at *3 (D. Minn. July 2, 2009); see also DOUglas LAYCOCK, MODERn AMERICAN REMEdies 750 (Concise 4th ed. 2012).

35. See, e.g., Brief of Research in Motion Ltd. as Amicus Curiae in Support of Neither Party, at 14, Apple, 757 F.3d 1286 (Nos. 2012-1548, 2012-1549); Brief for Nokia Corp. and Nokia Inc. as Amici Curiae in Support of Reversal and in Support of Neither Party at 2, Apple, 757 F.3d 1286 (Nos. 2012-1548, 2012-1549); Brief of Amicus Curiae BSA The Software Alliance in Support of Plaintiffs-Appellants at 6, Apple, 757 F.3d 1286 (Nos. 2012-1548, 12-1549). Other amici argued that injunctions should not be available. See, e.g., Brief of Amicus Curiae Fed. Trade Comm'n Supporting Neither Party at 14, Apple, 757 F.3d 1286 (Nos. 2012-1548, 2012-1549); Brief of Verizon Commc'ns Inc. et al. as Amici Curiae in Support of Neither Party at 29, Apple, 757 F.3d 1286 (No. 2012-1548).

36. Certain Elec. Devs., Including Wireless Commc'n Devs., Portable Music \& Data Processing Devs., and Tablet Comps., Inv. No. 337-TA-794, USITC at 47-48 (July 5, 2013) (Final) [hereinafter "Certain Elec. Devs."].

37. Some SSOs' IPR policies now specify that no implied license is granted by a RAND agreement. See, e.g., Microsoft, 963 F. Supp. 2d at 1187 ("IEEE-SA Standards Board Bylaws state that '[n]o license is implied by the submission of a Letter of Assurance."') (citation omitted).

38. Mark A. Lemley, Intellectual Property Rights and Standard-Setting Organizations, 90 CAL. L. Rev. 1889, 1926 (2002). Moreover, even if there is a basis for federal jurisdiction in the lawsuit, an appeal in the case would be to the regional circuit court, rather than the Federal Circuit, sacrificing the Federal Circuit's expertise on issues such as validity and infringement. Id. But the jurisdictional issue may arise under the contract view as well, at least where the standard adopter 
risk leaving the patentee with something less than a full RAND royalty in most cases by capping the implementer's litigation exposure - and the patentee's potential upside of litigation - at the payment of a RANDroyalty. ${ }^{40}$

\section{B. The Contract View}

\section{Overview of the Contract View}

The third view of RAND commitments is the contract view. Courts for the most part have concluded that the RAND declaration is a contract between the patentee and the SSO, enforceable against the patentee and its successors-in-interest ${ }^{41}$ by standards-implementers as third-party beneficiaries. $^{42}$ Under the contract view, courts interpret the RAND commitment as they would any other contract, and courts must determine the appropriate reasonable and non-discriminatory rate when the parties cannot agree. $^{43}$

Under the contract view, the RAND commitment is loosely analogous to an open-price contract that we see in other contexts. For example, Article 2 of the Uniform Commercial Code expressly permits parties to create a contract that omits the price term where they intend to do so. ${ }^{44}$ If the parties later cannot reach an agreement on the price, the court is left to adjudicate the price as "a reasonable price at the time for

sues the RAND-committed patentee for breach of the RAND commitment. See Microsoft Corp. v. Motorola, Inc., 795 F.3d 1024, 1034-36 (9th Cir. 2015) (holding that a breach claim does not arise under the patent laws for purposes of Federal Circuit jurisdiction).

39. See infra notes 60-63 and accompanying text.

40. This concern was the reason that Congress created enhanced damages. S. Rep. No. 791503, at 2 (2d Sess. 1946), reprinted in 1946 U.S. Code Cong. Serv. 1386, 1387. See also Panduit Corp. v. Stahlin Bros. Fibre Works, Inc., 575 F.2d 1152, 1158 (6th Cir. 1978); Laura B. Pincus, The Computation of Damages in Patent Infringement Actions, 5 HARV. J.L. \& TECH. 95, 124 (1991); Mitchell G. Stockwell, Implementing eBay: New Problems in Guiding Judicial Discretion and Enforcing Patent Rights, 88 J. PAT. \& TRADEMARK OfF. SOC'Y 747, 760 (2006) (all discussing concerns with a regime capping the infringer's exposure at the rate of a reasonable royalty).

41. Courts have uniformly allowed the RAND commitment to be enforced against successorsin-interest to the patentee. See In re Innovatio IP Ventures, LLC Patent Litig., 956 F. Supp. 2d 925, 933 (N.D. Ill. 2013); Michael A. Lindsay \& Robert A. Skitol, New Dimensions to the Patent Holdup Saga, 27-SPG ANTITRUST 34, Spring 2013, at 34.

42. See, e.g., Innovatio, 956 F. Supp. 2d at 933; Microsoft Corp., 963 F. Supp. 2d at 1181; Apple, Inc. v. Motorola Mobility, Inc., No. 11-CV-178-BBC, 2011 WL 7324582, at *10 (W.D. Wis. June 7, 2011); see also Commonwealth Sci. \& Indus. Research Org. v. Cisco Sys., Inc., No. 6:11CV-343, 2014 WL 3805817, at*3 (E.D. Tex. July 23, 2014).

43. The Federal Circuit offered some support for the contract view, requiring district courts to tailor jury instructions according to the language of "the actual RAND commitment at issue." Ericsson, Inc. v. D-Link Sys., Inc., 773 F.3d 1201, 1231 (Fed. Cir. 2014).

44. U.C.C. § 2-305 (2012). 
delivery." ${ }^{45}$ It is unsurprising that courts analyzing sellers' obligations to act in good faith in setting prices in open price contracts under Article 2 routinely look to whether the prices set are both commercially reasonable and nondiscriminatory. ${ }^{46}$

Open-price contracts risk creating holdup-type opportunistic behavior outside of the RAND context as well. Consider Milex Products v. Alra Labs. ${ }^{47}$ Alra was a drug manufacturer that agreed to manufacture a large quantity of a new generic drug for Milex, a drug company. ${ }^{48}$ Although the parties created an enforceable contract, they left the price of the drug to later agreement. ${ }^{49}$ Based on their agreement, Milex submitted an Abbreviated New Drug Application to the FDA, naming Alra as the manufacturer. ${ }^{50}$ When the FDA approved the application and the parties began to discuss price, Alra insisted on what Milex believed was an unreasonable price and unreasonable conditions. ${ }^{51}$ The appellate court characterized the situation in holdup terms:

We agree that the duty to bargain in good faith does not prohibit a party from bargaining to its own economic advantage. However, it is not an unreasonable inference that with Milex "locked in" to Alra as the manufacturer, Bhutani [Alra] tried to take advantage of the situation to force Milex to accept terms that had not been contemplated in the original contract and were not economically feasible for Milex.

The court affirmed the trial court's determination that Alra's holdup behavior breached its implied duty of good faith imposed on every contract under the Uniform Commercial Code. ${ }^{53}$ As in Milex, courts in the SEP context can eliminate patent holdup behavior - a key concern of the RAND obligation ${ }^{54}$ - by pointing to the patentee's duty of good faith and fair dealing implied in the RAND commitment under the contract

45. Id. at $\S 2-305(1)(\mathrm{b})$ (calling for a reasonable price at the time for delivery if "the price is left to be agreed by the parties and they fail to agree").

46. Shell Oil Co. v. HRN, Inc., 144 S.W.3d 429, 435-36 (Tex. 2004); Casserlie v. Shell Oil Co., 902 N.E.2d 1, 5-6 (Ohio 2009); United Food Mart, Inc. v. Motiva Enters., LLC, 457 F. Supp. 2d 1329, 1335-38 (S.D. Fla. 2005).

47. Milex Prods., Inc. v. Alra Labs., Inc., 603 N.E.2d 1226 (1992),

48. Id. at 1233 .

49. Id.

50. Id. at $1228-29$.

51. Id. at 1230 .

52. Id. at $1234-35$ (citation omitted).

53. Id. at 1233-35; see generally U.C.C. §§ 1-304 (2014), 2-305 (2012) (Article 2 specifically imposes this duty on parties fixing the price under an agreement with an open price term).

54. See In re Motorola Mobility, LLC at 3, F.T.C. File No. 121-0120 (Jan. 3, 2013) Dkt. No. 68-2. 
view. ${ }^{55}$

While the analogy between Article 2 and the RAND commitment offers some useful guidance with respect to the patentee's good-faith obligations, the analogy is not perfect. ${ }^{56}$ In the sale of goods context, the buyer knows whether he is using the seller's tangible property, and the seller is also likely to know when the buyer is using his property. But with patents, implementers often cannot be certain whether they are "using" the patentee's property, because the patent may be invalid or may not read on the standard, even though the patentee claims that it is essential to the standard. And, because of the non-rivalrous nature of intellectual property, the implementer may be able to use the patented technology without the patentee discovering the implementer's use.

\section{The Contract View as It Relates to Opportunism}

A central purpose of the RAND commitment is to avoid patentee opportunism, ${ }^{57}$ and the contract view serves this purpose well. Under the contract view, the RAND-committed patentee is obligated to negotiate with the implementer in good faith, ${ }^{58}$ and if it fails to do so, it can be liable for breaching its RAND commitment and could potentially even be subject to antitrust liability. ${ }^{59}$ But the RAND commitment is also intended to ensure that the patentee receives the value of its contribution to the standard, ${ }^{60}$ and this purpose will be disserved unless the implementers are somehow incentivized to negotiate in good faith toward a RAND license.

The alternative views of the RAND commitment - the implied license view and the waiver view-disserve this second purpose if they lead to below-RAND negotiated licenses. Under either of those views, the RAND rate sets the maximum recoverable damages for the patentee

55. See, e.g., Microsoft Corp. v. Motorola, Inc., 963 F. Supp. 2d 1176, 1184 (W.D. Wash. 2013); Realtek Semiconductor Corp. v. LSI Corp., No. C-12-03451 RMW, 2012 WL 4845628, at*4 (N.D. Cal. Oct. 10, 2012). This may depend on whether there is a duty of good faith and fair dealing implied in every contract in the particular state or country whose laws are used.

56. Unlike tangible property, intellectual property is neither scarce nor rivalrous, so that multiple people can make use of it simultaneously.

57. U.S. Dep't of Justice \& U.S. Patent and Trademark Office, Policy Statement on Remedies for Standards-Essential Patents Subject to Voluntary F/RAND Commitments 5 (Jan. 8, 2013), http://www.uspto.gov/about/offices/ogc/Final_DOJ-PTO_Policy_Statement_on_FRAND_SEPs_18-13.pdf [hereinafter Policy Statement].

58. See Microsoft Corp. v. Motorola, Inc., No. C10-1823JLR, 2013 WL 5373179, at *2 (W.D. Wash. Sept. 24, 2013).

59. Broadcom Corp. v. Qualcomm Inc., 501 F.3d 297, 314 (3d Cir. 2007); Research In Motion Ltd. v. Motorola, Inc., 644 F. Supp. 2d 788, 792-94 (N.D. Tex. 2008).

60. Policy Statement, supra note 57, at 8. 
in an infringement action against the implementer. ${ }^{61}$ In that situation, implementers have no remedial incentive to reach a license with the patentee. $^{62}$ If the most that a patentee can hope to get through litigation, and the most an implementer will have to pay as a result of litigation, is a RAND royalty, then implementers likely will only agree to license the patent for something less than the RAND rate, leaving the patentee shortchanged. ${ }^{63}$ This is known as patent holdout or reverse holdup. ${ }^{64}$

The contract view of the RAND commitment risks suffering from the same shortcomings as the implied license view and the waiver view. The contract view-by imposing an obligation on the patentee to negotiate toward a RAND-rate license in good faith-risks exposing the patentee to reverse holdup unless the implementer is incentivized to reach a RAND-rate license. This is where the available remedies come into play. I argue in the next section that it is not necessary to create unique remedial doctrines in RAND cases to avoid both patent holdup and reverse holdup; the RAND commitment, coupled with careful attention to traditional remedial doctrines, can accomplish both of these ends.

\section{THE ROLE OF REMEDIES IN RAND COMMITMENTS}

Eliminating patent holdup without creating an environment conducive to implementer opportunism will require courts to strike a careful balance with respect to remedies available for infringement of RAND-encumbered patents. ${ }^{65}$ These remedies are "the subject of substantial, often contradictory, academic commentary" $" 66$ and court

61. See supra Part II.A. Technically, under the implied license view, there would be no infringement action, but merely a quasi-contractual action against the implementer for payment of the RAND rate.

62. Of course, implementers may experience moral pressures to seek a license because it is the right thing to do, or they may experience environmental pressures to seek a license to ensure a positive reputation in the industry and in the SDO, but they will not have any remedial pressure.

63. See Mark A. Lemley \& Carl Shapiro, A Simple Approach to Setting Reasonable Royalties for Standard-Essential Patents, 28 BERKELEY TECH. L.J. 1135, 1153 (2013) ("A commitment to license on reasonable terms is not a commitment to be whipsawed by a potential licensee.").

64. See Anne Layne-Farrar, Moving Past the SEP RAND Obsession: Some Thoughts on the Economic Implications of Unilateral Commitments and the Complexities of Patent Licensing, 21 Geo. Mason L. REV. 1093, 1098 (2014); F. Scott Kieff \& Anne Layne-Farrar, Incentive Effects from Different Approaches to Holdup Mitigation Surrounding Patent Remedies and StandardSetting Organizations, 9 J. Competition L. \& ECON. 1091, 1097 n.18, 1107 (2013).

65. Brief for Am. Intell. Prop. Law Ass'n as Amicus Curiae Supporting Neither Party, Microsoft Corp. v. Motorola Mobility, Inc., No. 14-35393, 2014 WL 4802384 (9th Cir. 2014) [hereinafter Am. Intell. Brief].

66. In re Innovatio IP Ventures, LLC Patent Litig., 921 F. Supp. 2d 903, 916 (N.D. Ill. 2013). 
opinions. ${ }^{67}$ Optimal remedies for infringement of RAND-encumbered patents should neither enable the patentee to extract supracompetitive licensing fees based on the value of the standard nor enable implementers to free-ride. Relatedly, optimal remedies should encourage both parties to bargain in good faith in an effort to reach a RAND-rate license.

To accomplish this goal, we must remove any incentives that the parties might have to resist agreement at the RAND rate. Those incentives exist on the patentee's side when it thinks it can force the implementer into an above-RAND license under threat of an injunction or enhanced damages. Those incentives arise on the implementer's side when it incurs no risk from committing knowing infringement (that is, when its liability after trial is limited to the RAND rate) and when it thinks that it can compel the patentee to enter into a below-RAND license (for example, because of litigation risks or expenses). The proper balance of these remedies is the subject of this section.

\section{A. Restoring the Rightful Position}

Three oft-cited remedial goals of our justice system are to (1) restore the injured party to its rightful position (the restorative interest); (2) protect the rightful position of society's members (the protective interest); and (3) coerce utility-enhancing conduct from society (the coercive interest). ${ }^{68}$ When it comes to restoring the patentee to its

67. See id.; Am. Intell. Brief, supra note 65 , at *3 (noting that SSOs' intellectual property rights policies are "carefully balanced to ... advance two equally important goals: ensuring reasonable access to implementers who want to practice a standard, while providing adequate compensation through licensing of standard-essential patents").

68. Marco Jimenez, Remedial Consilience, 62 EMORY L.J. 1309, 1313-14 (2013). I assume here that the patentee's ability to monetize the patent has become part of the patentee's "rightful position." Id. For these purposes, it does not matter whether we value the patentee's rightful position under an Aristotelian corrective-justice model or under a utilitarian model — under either view, restoring and preserving the rightful position are important policy goals. DOUGLAS LAYCOCK, MODERN AMERICAN REMEDIES 14-15, 304-05 (Concise 4th ed. 2012). Conventional wisdom suggests that patents are primarily utilitarian. See, e.g., David S. Olson, Taking the Utilitarian Basis for Patent Law Seriously: The Case for Restricting Patentable Subject Matter, 82 TEMP. L. REV. 181, 182-83 (2009). But there are some thoughtful arguments that Lockean theory supports patent rights. See Adam Mossoff, Why Intellectual Property Rights? A Lockean Justification, LIBRARY OF LAW AND LIBERTY (May 4, 2015), http://www.libertylawsite.org/liberty-forum/why-intellectualproperty-rights-a-lockean-justification/. This distinction may lead to differing views on what the positive law ought to be with respect to, for example, the patent term or independent creation but, once the positive law has answered these questions, the "rightful position" analysis is the same. Thus, "patent damage awards should reflect the economic realities of the market in which the patented technology competes by rendering the patentee no worse off, but also no better off, than it would have been absent the infringement." Michel, supra note 33, at 896. 
rightful position for past infringement, all three of the RANDcommitment views are in agreement as to the proper remedy: a RANDcommitted patentee will be restored to its rightful position by a RANDrate royalty payment.

Depending on one's view, a remedy for past harm aims to serve the restorative interest by restoring the injured party to its rightful position or the coercive interest by incentivizing utility-enhancing conduct, forcing the wrongdoer to internalize the cost of harm it inflicts on others. ${ }^{69}$ Under either conception, this usually means providing a monetary award-measured as the value of that which the plaintiff lost-as a substitutionary remedy where in-kind relief is not possible, such as in the case of past patent infringement. The normal measures of damages for patent infringement are lost profits (if provable) or a "reasonable royalty." 70

In the ordinary patent infringement case, money damages can be a very poor substitute for the right to exclude, because of two uncertainties: we usually cannot know (1) whether the patentee would have been willing to license the infringer in pre-infringement negotiations for some amount of money and (2) whether the parties would have been able to reach an agreement on the licensing fees. If money is incommensurable with the right to exclude (perhaps, for example, where the patentee found the implementer's use morally objectionable and would not have licensed it for any price ${ }^{71}$ ) then no monetary remedy can truly restore the patentee to its rightful position. Similarly, if the patentee would not have agreed to license the infringer for any amount the infringer could pay, or for the amount determined by the court to be a reasonable royalty, the award is undercompensatory. This can occur because of the constraints of the reasonable royalty award, in which the infringer's ability to pay and intended use of the patent may limit the amount that the factfinder determines to be a reasonable royalty well below the patentee's valuation of the right. ${ }^{72}$

69. The coercive interest rests on the view that the law is significantly or entirely utilitarian. See Richard A. Posner, EConomic Analysis of the LAW 31-34 (9th ed. 2014). This interest will depend in part on whether Congress has appropriately set incentives to invent and disclose through the patent laws, but this article assumes that those incentives are appropriately set. See S. COMm. ON THE Judiciary, PATENT ReEXAmination, S. REP. No. 96-617, at 9 (1980).

70. 35 U.S.C. § 284 (2012); Trell v. Marlee Elec. Corp., 912 F.2d 1443, 1445 (Fed. Cir. 1990).

71. Some would say this is not properly an uncertainty - that money and the right to exclude are always commensurable for some value. See Jeanne L. Schroeder, The Laconomics of Apples and Oranges: A Speculative Analysis of the Economic Concept of Commensurability, 15 YALE J.L. \& HUMAN. 347, 348-49 (2003).

72. See Lucent Techs., Inc. v. Gateway, Inc., 580 F.3d 1301, 1333 (Fed. Cir. 2009) (extent of use); Century Wrecker Corp. v. E.R. Buske Mfg. Co., 898 F. Supp. 1334, 1338 (N.D. Iowa 1995) 
In the RAND context, however, we can be much more confident in the ability of money damages to restore the patent holder to its rightful position. We know that the patentee must be willing to license all comers, so the first uncertainty is eliminated. And, having made a RAND commitment, the patentee has informed us that it values standard incorporation plus a "reasonable and non-discriminatory" licensing rate - which it knows is subject to judicial determination in a disputemore than it values the right to exclude under its patent. It has already received standard incorporation, so an award of a reasonable and nondiscriminatory license amount should restore the patentee's rightful position. That is not to say that the RAND rate is always easy to determine, but courts have long been engaged in calculating reasonable royalties, so that a damages award at a judicially determined RAND rate will likely approximate the patentee's rightful position. ${ }^{73}$

\section{B. Protecting the Rightful Position}

All three RAND views are in agreement about the proper remedy to restore the RAND-committed patentee to its rightful position. And, in theory, a patentee who is truly restored to its rightful position should be indifferent between avoiding the infringement altogether and being compensated after enduring the infringement. But, in reality, plaintiffs will rarely be indifferent between the two, because litigation requires the plaintiff to invest non-recoupable resources in the process, ${ }^{74}$ so that the plaintiff is rarely fully restored to his "rightful position."

In patent litigation, the plaintiff can recover its attorneys' fees only in "exceptional cases" and, despite the Supreme Court's recent expanded gloss on the term, ${ }^{75}$ the plaintiff remains relatively unlikely to recover fees. ${ }^{76}$ This shortfall from achieving the rightful position post-litigation is a function of the American Rule, and it is hardly unique to patent

(ability to pay).

73. See Trell, 912 F.2d at 1445 . This is especially true if, as I earlier posited, the RAND commitment entails an agreement to permit courts to determine the RAND rate where the parties are unable to agree, like an open-price term contract under the Uniform Commercial Code. See supra Part II.B.1.

74. See Michael Risch, Why Do We Have Trade Secrets?, 11 MARQ. InTELl. Prop. L. ReV. 1, 59-60 (2007) (" [I]f transaction, administrative, and enforcement costs are zero, and if all parties have perfect information, then all parties would be indifferent between damages (a liability rule) and an injunction (a property rule). However, in the real world parties do not have perfect information, and there are transaction costs.").

75. Octane Fitness, LLC v. ICON Health \& Fitness, Inc., 134 S. Ct. 1749, 1756-57 (2014).

76. Under Professor Lemley's implied license view, the patentee would have no grounds to recover fees, unless it is independently permitted by state contract law. See Lemley, supra note 29, at 1925-26. 
cases, but it is nevertheless a real cost borne by the successful patentee in an infringement action. Further, even if the plaintiff recovers its attorneys' fees, it is unlikely to recover all of them, because courts often reduce the fee award from the amount incurred. ${ }^{77}$ Finally, even if the plaintiff recovers all of its attorneys' fees, it would still prefer a RANDrate license over RAND-rate damages because, during litigation, the plaintiff must divert its financial and human resources to assist in the litigation, engaging in such tasks as document searches, evidence review, testifying, meetings, and the like. ${ }^{78}$

Moreover, the vast majority of cases settle. ${ }^{79}$ If the implementer's consequences for infringement are equal only to payment at the RANDrate-the same rate that the infringer would be obligated to pay if it lawfully licensed the patent - the implementer has no remedial incentive to avoid the infringing conduct and license the patent. ${ }^{80}$ Its infringement might go unnoticed, ${ }^{81}$ in which case it pays nothing; and, if the infringement is discovered, its worst-case scenario is, after litigation, to simply pay the RAND rate that it would have been obliged to pay to license the patent ex ante. In these circumstances, infringers, if their infringement is discovered, can safely expect to negotiate a settlement at a substantial discount from the RAND rate, even if validity and infringement are likely. ${ }^{82}$ As the Department of Justice and the Patent

77. Jeff A. Ronspies, Does David Need a New Sling? Small Entities Face a Costly Barrier to Patent Protection, 4 J. Marshall Rev. InTEll. Prop. L. 184, 199 (2004).

78. Pauline H. Tesler, Client Relations: Tips from A Collaborative Practitioner, 21 AlternAtives to High COST LiTIG. 13 (2003) (describing indirect transactional costs of litigation).

79. Andrey Spektor, The Death Knell of Issue Certification and Why That Matters After WalMart v. Dukes, 26 ST. ThOMAS L. Rev. 165, 190 n.2 (2014) (describing study that estimated ninetyseven percent of cases settle or are dismissed before trial).

80. See Certain Elec. Devs., supra note 36, at 63 ("In reverse patent hold-up, an implementer utilizes declared-essential technology without compensation to the patent owner under the guise that the patent owner's offers to license were not fair or reasonable. The patent owner is therefore forced to defend its rights through expensive litigation.").

81. Professor Lichtman recognized this concern, but found it diminished because standardcompliant products are usually marketed as such, meaning that patentees will often be able to discover infringing products. See Lichtman, supra note 28, at 1041-42. But standards are most useful when there are many players in an industry and many parties who would implement the standards that are adopted, making discovery of infringing products more difficult. For example, as of February 22, 2015, an Amazon search for "802.11 router" (that is, a router that complies with the IEEE 802.11 standard) resulted in 8,850 hits, not to mention other wireless devices, such as computers, smart televisions, media streaming devices, gaming systems, and USB wireless receivers, which are also 802.11 compliant.

82. As Judge Posner recognized, both parties would bear attorneys' fees during litigation. Apple, Inc. v. Motorola, Inc., 869 F. Supp. 2d 901, 915 (N.D. Ill. 2012), rev'd in part, 757 F.3d 1286 (Fed. Cir. 2014). But the patentee must spend significant fees and substantial discovery costs to recover, whereas the implementer need not mount an expensive defense if its approach is merely to use the patentee's RAND commitment opportunistically - it can simply force the plaintiff to prove its case at substantial expense, and then accept its judgment of liability at the RAND rate. More 
and Trademark Office noted in a joint policy statement, "the risk of a refusal to license ... increases where the putative licensee believes its worst-case outcome after litigation is to pay the same amount it would have paid earlier for a license." 83 This is particularly true because "information asymmetries appear most likely to disfavor the patent holder in negotiations, suggesting that . . . the patent holder will probably be substantially handicapped in its ability to achieve an especially favorable negotiated result." 84 Thus, in the absence of a remedial incentive for implementers to license the patent, the patentee will not achieve its rightful position, nor will the infringer fully internalize the societal cost of its infringement. ${ }^{85}$

The protective interest recognizes that, at least in cases where the plaintiff will not be fully restored to its rightful position, we should attempt to avoid harm rather than to permit the harm but require compensation after the fact. In most patent cases, two remedial mechanisms serve the protective interest. The first is the court's ability to award enhanced damages, ${ }^{86}$ and the second is injunctive relief. But the implied license view and the waiver view would eliminate both of these remedies for infringement of RAND-encumbered patents. ${ }^{87}$ As discussed above, and as scholars have generally recognized, foreclosing these two remedies has significant drawbacks because, while eliminating patentee opportunism, it creates an environment conducive to implementer opportunism. ${ }^{88}$ The optimal solution should set a standard for enhanced damages and injunctive relief that would minimize

importantly, the patentee must discount for litigation risk much more substantially than merely the inverse of the infringer's risk of patent validity, as described in more detail below. See infra notes 254-258 and accompanying text.

83. Policy Statement, supra note 57, at 7 n.15.

84. John M. Golden, "Patent Trolls" and Patent Remedies, 85 TEX. L. REV. 2111, 2133 (2007).

85. See generally Joanna M. Shepherd, Tort Reforms' Winners and Losers: The Competing Effects of Care and Activity Levels, 55 UCLA L. REV. 905, 915-18 (2008) (discussing law-andeconomics theory that tortfeasors pay damages to force them to internalize costs of wrongdoing).

86. Congress's express purpose in instituting enhanced damages was to "discourage infringement of a patent by anyone thinking that all he would be required to pay if he loses the suit would be a royalty." S. Rep. No. 79-1503, at 2 (2d Sess. 1946), as reprinted in 1946 U.S. Code Cong. Serv. 1386, 1387. See also sources cited supra note 40.

87. In re Innovatio IP Ventures, LLC Pat. Litig., 921 F. Supp. 2d 903, 917 n.10 (N.D. Ill. 2013) (collecting commentators' positions); Joseph Scott Miller, Standard Setting, Patents, and Access Lock-in: RAND Licensing and the Theory of the Firm, 40 IND. L. REV. 351, 375 (2007); Lichtman, supra note 28, at 1048-49; see also John D. Harkrider, Seeing the Forest Through the Seps, ANTITRUST, Summer 2013, at 22, 23.

88. See, e.g., Lichtman, supra note 28, at 1048-49 ("[U]nder my interpretation, RAND does little to encourage standard-setting participants to negotiate rather than litigate.... The upshot might be that patent holders who agree to the RAND commitment will in the end be undercompensated."). 
potential opportunism by either party. The contract view, coupled with a careful application of traditional remedial mechanisms, is well suited to this end.

Below, I consider the application of three potential remediesinjunctive relief, enhanced damages, and an ongoing royalty-in the RAND context. Prior discussions of the other views of the RAND commitment have simply treated injunctive relief and enhanced damages together; because they both serve the protective interest, they should either both be allowed or neither be allowed. I argue that the traditional application of the elements of these remedies - as well as the goals of the protective interest and the policies behind the RAND commitmentmake enhanced damages the most useful of these remedies in the RAND context.

\section{The Prohibitory Injunction}

The prohibitory injunction can serve the protective interest in two distinct ways. ${ }^{89}$ First, an injunction against future infringement serves the protective interest by foreclosing future infringement after the injunction is entered - the injunctive command, enforceable on pain of contempt, works to ensure that the defendant will not infringe the patent in the future. Second, the fear of injunctions may incentivize would-be infringers to seek a license rather than to attempt undetected infringement. (This depends on the infringer's need to invest nonrecoupable costs, such as re-tooling machines or purchasing supplies, in the infringement. Would-be infringers will hesitate to invest such costs if an injunction could prevent them from realizing any profit from their investment. ${ }^{90}$ )

In the RAND context, partly as a result of the failure to distinguish between these two different ways that injunctions serve the protective

89. For utilitarians, injunctions, like all other remedies, serve the coercive interest. Injunctions ensure that the wrongdoer negotiates for a voluntary transaction (a Pareto positive transaction in which net utility is enhanced) rather than unilaterally take the other party's property (in which case we cannot know whether utility is enhanced following the judicial remedy). This view of injunctions, while differing from protection of the rightful position qua rightful position, nevertheless aligns with the protective interest in terms of the normative role of injunctive relief.

90. The threat of injunctive relief does not incentivize would-be infringers to seek a license if the infringers are not heavily tied down with sunk costs. Thus, a seller who simply imports patented products, marks them up, and then resells them would not necessarily be disincentivized by the threat of an injunction. In such cases, enhanced damages serve the protective interest in a way that injunctions do not. See Maier Brewing Co. v. Fleischmann Distilling Corp., 390 F.2d 117, 122-23 (9th Cir. 1968) (justifying disgorgement of profits in trademark cases because an injunction "does not necessarily protect... from similar... acts," so that "the courts must ... make acts of ... deliberate trade-mark piracy, unprofitable"). 
interest, "the question of whether a RAND obligation precludes an injunction is 'muddled' and 'the subject of substantial, often contradictory, academic commentary." "91 Consider the following examples of the wide array of commentary and judicial opinions. In Apple v. Motorola ${ }^{92}$ four federal judges-Judge Posner, sitting by designation at the trial level, and Judges Rader, Reyna, and Prost at the Federal Circuit - all differed with respect to whether and to what extent injunctive relief should be available in the RAND context. ${ }^{93}$ In a separate case, the Ninth Circuit found implicit in a RAND commitment, "at least arguably, a guarantee that the patent-holder will not take steps to keep would-be users from using the patented material, such as seeking an injunction." 94 Some commentators have argued that a RAND commitment precludes the patentee from seeking injunctive relief, ${ }^{95}$ while others have argued in favor of retaining injunctive relief. ${ }^{96}$ And some courts have held that a patentee breaches its RAND commitment if it seeks injunctive relief without at least first making a good-faith licensing offer to the implementer. ${ }^{97}$ In a 2013 FTC consent order, Google and Motorola agreed not to seek injunctive relief for RANDencumbered patents unless the licensee refused to license the patent on any terms. ${ }^{98}$ The International Trade Commission, on the other hand, has been willing to issue injunctions where RAND-encumbered patents were involved, most famously in favor of Samsung against Apple. ${ }^{99}$ And the

91. In re Innovatio IP Ventures, LLC Patent Litig., No. 11C9308, 2013 WL 5593609, at *11 (N.D. Ill. Oct. 3, 2013) (citing In re Innovatio IP Ventures, LLC Patent Litig., 921 F. Supp. 2d 903, 916 (N.D. Ill. 2013)).

92. 757 F.3d 1286 (Fed. Cir. 2014), overruled by Williamson v. Citrix Online, LLC, 792 F.3d 1339 (Fed. Cir. 2015).

93. See infra Part III.B.1.a.

94. Microsoft Corp. v. Motorola, Inc., 696 F.3d 872, 884 (9th Cir. 2012).

95. See Licthman, supra note 28, at 1042-43; Lemley, supra note 3, at 158; Letter from Bruce H. Watrous, Jr. on behalf of Apple to European Telecomms. Standards Inst. (Nov. 11, 2011), http://www.scribd.com/doc/80899178/11-11-11-Apple-Letter-to-ETSI-on-FRAND ("Seeking an injunction would be a violation of the party's commitment to FRAND licensing.").

96. See, e.g., Kieff \& Layne-Farrar, supra note 64, at 1113.

97. See, e.g., Realtek Semiconductor Corp. v. LSI Corp., 946 F. Supp. 2d 998, 1008 (N.D. Cal. 2013). The damages from such a breach would presumably be the attorneys' fees expended in fighting the claim for injunctive relief.

98. In re Motorola Mobility LLC \& Google Inc., Docket No. C-4410, Decision and Order (July 23 ,

http://www.ftc.gov/sites/default/files/documents/cases/2013/07/130724googlemotorolado.pdf.

99. See id.; see also Certain Elec. Devs., supra note 36 (technically, the ITC issues exclusion orders, but they are functionally equivalent to injunctive relief); Letter from Ambassador Michael B.G. Froman to Hon. Irving A. Williamson (Aug. 3, 2013), https://ustr.gov/sites/default/files/08032013\%20Letter_1.PDF (issued by United States Trade Representative Michael B.G. Froman to the ITC announcing President Obama's disapproval of the ITC exclusion order, effectively reversing the ITC's decision; the disapproval was based largely on 
Department of Justice released a Joint Policy Statement with the Patent and Trademark Office arguing that injunctions should not usually be available for infringement of a RAND-encumbered patent, with some notable exceptions. ${ }^{100}$

The concern about injunctions in the SEP context relates to the potential for patentee opportunism. If an implementer is enjoined from practicing a patent essential to an industry standard, the implementer's prior investments in the standard would be nullified, and the implementer would be effectively excluded from industry participation. Thus, the threat of this injunction provides the patentee with leverage to extract supracompetitive royalties from the implementer. But the injunction-asopportunism possibility is not unique to patent law-a plaintiff can use the threat of an injunction to extract the value of sunk costs in any situation where a threatened injunction would nullify those costs.

The case of Whitlock $v$. Hilander Foods, Inc. offers an example of such a case outside of patent law. ${ }^{101}$ In Whitlock, the defendant grocery store began building a retaining wall whose footings extended eighteen to twenty inches onto Whitlock's property, below ground. ${ }^{102}$ After Whitlock noticed the encroachment, the parties began negotiating for a lease or purchase of the property at issue, but were unable to reach a resolution. ${ }^{103}$ Whitlock sued, seeking an injunction that would have forced Hilander to tear down the newly constructed $\$ 1.5$ million wall and build another one eighteen inches back. ${ }^{104}$ This would have allowed Whitlock to command a premium for his property rights, enabling Whitlock to demand from Hilander not only the value of the property, but anything less than the cost to Hilander to tear down and rebuild the wall. ${ }^{105}$

Where, as in Whitlock and as in most SEP cases, it appears that the plaintiff is seeking injunctive relief merely as bargaining leverage, ${ }^{106}$ the injunction will generally be unavailable under the "traditional four-factor test" for permanent injunctive relief set out in eBay Inc. $v$.

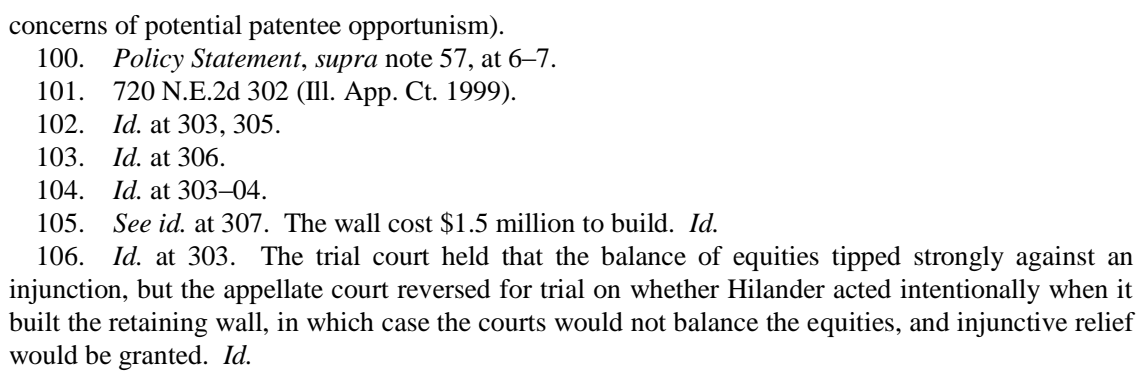
injunction, but the appellate court reversed for trial on whether Hilander acted intentionally when it built the retaining wall, in which case the courts would not balance the equities, and injunctive relief would be granted. $I d$. 
MercExchange, L.L.C. ${ }^{107}$ Thus the Federal Circuit recently declined to "create, as some amici urge, a separate rule or analytical framework for addressing injunctions for []RAND-committed patents," emphasizing that " $[\mathrm{t}]$ he framework laid out by the Supreme Court in eBay... provides ample strength and flexibility for addressing the unique aspects of []RAND committed patents."108 The $e$ Bay factors are: (1) irreparable injury; (2) inadequacy of legal remedies; (3) balance of the parties' hardships; and (4) public interest. ${ }^{109}$

\section{a. Irreparable Harm/Inadequacy of the Legal Remedies}

The first and second factors of the eBay test reflect the same considerations: namely, whether money damages (or, in theory, some other legal remedy) will adequately compensate the patentee for any harm to its property interests. ${ }^{110}$ Above, I argue that a RAND-rate royalty places the patentee in its rightful position and, consequently, adequately compensates the patentee. ${ }^{111}$ This is similar to courts outside of the RAND context that have concluded that money damages are usually adequate when the patentee has been a willing licensor of all comers. ${ }^{112}$

In Apple v. Motorola, Judge Posner opined that the RAND commitment resulted in adequate legal remedies:

I don't see how, given FRAND, I would be justified in enjoining Apple from infringing .... unless Apple refuses to pay a royalty that meets the FRAND requirement. By committing to license its patents on FRAND terms, Motorola committed to license the [patent] to anyone willing to

107. eBay Inc. v. MercExchange, L.L.C., 547 U.S. 388, 391-93 (2006).

108. Apple Inc. v. Motorola, Inc., 757 F.3d 1286, 1331-32 (Fed. Cir. 2014), overruled by Williamson v. Citrix Online, LLC, 792 F.3d 1339 (Fed. Cir. 2015).

109. eBay, 547 U.S. at 391.

110. See, e.g., ActiveVideo Networks, Inc. v. Verizon Commc'ns, Inc., 694 F.3d 1312, 1337 (Fed. Cir. 2012); Acumed LLC v. Stryker Corp., 551 F.3d 1323, 1327 (Fed. Cir. 2008); Bianco v. Globus Med., Inc., No. 2:12-CV-00147-WCB, 2014 WL 1049067, at *1 (E.D. Tex. Mar. 17, 2014); MercExchange, L.L.C. v. eBay, Inc., 500 F. Supp. 2d 556, 569 n.11 (E.D. Va. 2007) ("The irreparable harm inquiry and remedy at law inquiry are essentially two sides of the same coin ....").

111. See supra Part III.A; see also Realtek Semiconductor Corp. v. LSI Corp., 946 F. Supp. 2d 998, 1006-07 (N.D. Cal. 2013).

112. See, e.g., ActiveVideo, 694 F.3d at 1340. Outside of the RAND context, courts often examine the patentee's past licensing practices in evaluating requests for injunctive relief. Id. Factors include (1) whether the patentee has been a willing licensor; (2) the identity of parties to whom past licenses were given; (3) market experience since the licenses were granted; and (4) the identity of the new infringer. Apple Inc. v. Samsung Elecs. Co., 735 F.3d 1352, 1369-70 (Fed. Cir. 2013) (citing Acumed LLC v. Stryker Corp., 551 F.3d 1323, 1328 (Fed. Cir. 2008)). The RAND commitment impacts all of these factors: the patentee must willingly license all comers, regardless of what has occurred in the market since prior licenses. 
pay a FRAND royalty and thus implicitly acknowledged that a royalty is adequate compensation for a license to use that patent.

Thus, "[a] FRAND royalty would provide all the relief to which Motorola would be entitled if it proved infringement, ... and thus it is not entitled to an injunction."

On appeal in Apple v. Motorola, all three judges on the Federal Circuit panel wrote separately to address the matter of injunctive relief, but the court affirmed Judge Posner's summary judgment rejecting Motorola's injunction claim over a dissent from then-Chief Judge Rader. Judge Reyna, who wrote the opinion of the court, disagreed with Judge Posner's analysis "[t]o the extent" that he "applied a per se rule that injunctions are unavailable for SEPs." "115 Judge Reyna hypothesized that "an injunction may be justified where an infringer unilaterally refuses a FRAND royalty or unreasonably delays negotiations to the same effect." "To be clear, this does not mean that an alleged infringer's refusal to accept any license offer necessarily justifies issuing an injunction." 117

Judge Prost wrote separately because she thought Judge Reyna's opinion left the door to injunctive relief open too widely - she disagreed with the "suggestion that an alleged infringer's refusal to negotiate a license justifies the issuance of an injunction."118 Judge Prost noted that a threat of injunctive relief for an SEP would deter implementers from raising even good-faith challenges about validity and infringement. ${ }^{119}$ She thought that an implementer with a good-faith challenge to validity or noninfringement "should not necessarily be punished for less than

113. Apple, Inc. v. Motorola, Inc., 869 F. Supp. 2d 901, 913-14 (N.D. Ill. 2012), rev'd in part, 757 F.3d 1286 (Fed. Cir. 2014). Judge Posner also used the parties' attempts to calculate damages against them in their request for an injunction: "And neither has acknowledged that damages for the infringement of its patents could not be estimated with tolerable certainty. On the contrary, each insists not only that damages are calculable but that it has calculated them." Id. at 916. In general, the fact that the plaintiff has calculated damages for past infringement does not mean that the damages are an adequate legal remedy for future infringement. Our system provides for substitutionary relief to a patentee for infringement, not because monetary damages are easily calculated or even necessarily commensurable with the right to exclude, but because the right to exclude cannot be restored in-kind. Thus, a patentee does not concede the adequacy of money damages merely by offering a calculation of damages for past infringement.

114. Id. at 915 .

115. Apple, 757 F.3d at 1331. It is not clear that Judge Posner ever articulated such a per se rule in his opinion.

116. Id. at 1332 .

117. Id.

118. Id. at 1342 (Prost, J., dissenting in part).

119. See id. 
eager negotiations."120 Judge Prost would completely remove "a party's pre-litigation conduct in license negotiations" from the determination of the patentee's request for injunctive relief. ${ }^{121}$

Judge Rader dissented on this point. He agreed with Judge Reyna that injunctions should be available where the implementer refuses to negotiate for a license, but he added that the record was sufficient to go to trial on the question of whether Apple was an unwilling licensee. ${ }^{122}$ He suggested that "Motorola should have had the opportunity to prove its case that Apple's alleged unwillingness to license or even negotiate supports a showing that money damages are inadequate and that it suffered irreparable harm."

The implicit disagreement between Judge Prost and the other judges relates to whether the injunction should serve the protective interest only in the first way mentioned above (proscribing post-judgment infringement) or whether it should also serve the protective interest in the second way (coercing license negotiations by threatening to nullify an implementer's sunk costs or even eliminate the implementer from the industry). By arguing that pre-litigation conduct should not be considered, Judge Prost would limit injunctive relief to this first means of serving the protective interest. The other judges, by suggesting that injunctive relief might be available against an implementer who unreasonably delays license negotiations, would allow injunctive relief to serve the protective interest in both capacities.

While it is not surprising that the judges might disagree about this, it is odd for them to characterize the availability of injunctive relief in these cases as a function of the adequacy of the legal remedies. The implementer's pre-litigation conduct would not impact the adequacy of a RAND-rate post-litigation. In other words, once the parties are in litigation, a RAND-rate royalty serves the restorative interest for any completed infringement equally well regardless of the implementer's pre-litigation conduct; the point of the license-coercing aspect of the threat of injunctive relief is to incentivize future parties to negotiate toward a RAND-rate agreement without litigation. Regardless of the implementer's prelitigation conduct - whether the implementer engaged in good-faith negotiations or refused to negotiate altogether-the restorative ability of a damages award for past infringement remains unchanged. Whether legal remedies are adequate for future infringement

120. Id

121. Id. at 1343.

122. Id. at 1332-33 (Rader, J., dissenting in part).

123. Id. at 1334 . 
cannot turn on an implementer's past behavior. Thus, it seems strange for Judge Posner to opine that a RAND commitment renders legal remedies adequate "unless Apple refuses to pay a royalty that meets the FRAND requirement." 124

It is possible, however, for damages to be an inadequate remedy for infringement of RAND-encumbered patents. As Judge Posner recognized, the infringer's insolvency may render the legal remedy inadequate. ${ }^{125}$ This is not controversial-most courts agree that an uncollectible damages award would not be an adequate legal remedy. ${ }^{126}$ In addition, legal remedies may be inadequate for ongoing future infringement because complete compensation would require multiple successive lawsuits, and most courts agree that the damages are inadequate for future wrongdoing where the plaintiff would have to file periodic lawsuits to recover those damages. ${ }^{127}$

But none of this explains why Judges Posner, Reyna, and Rader would hinge the determination of the adequacy of legal remedies for future infringement on the implementer's pre-lawsuit conduct. It is hard to understand how their concern in such cases rests on the adequacy vel non of legal remedies. More likely, their analysis simply hinges on the desire to coerce implementers to negotiate toward a RAND-rate license in good faith - that is, to supply the incentive necessary under the contract view to avoid implementer opportunism. I argue below that this incentive would be better served by enhanced damages. ${ }^{128}$

\section{b. Balance of Harms}

The second eBay factor for injunctive relief is the balance of harms. Courts considering injunctive relief must balance the relative harms that would result to each party from the presence or absence of an injunction. In most cases of RAND-encumbered SEPs, we would expect the balance of harms to tip strongly against an injunction. ${ }^{129}$ In SEP cases, the

124. Apple, Inc. v. Motorola, Inc., 869 F. Supp. 2d 901, 913-14 (N.D. Ill. 2012), rev'd in part, 757 F.3d 1286 (Fed. Cir. 2014). Similarly, the Federal Circuit discussed potential injunctions against implementers who were unwilling to pay the RAND rate. Apple, 757 F.3d at 1332.

125. Apple, 869 F. Supp. $2 \mathrm{~d}$ at 916.

126. DOUGLAS LAYCOCK, THE DEATH OF THE IRREPARABLE INJURy RULE 86-87 n.22 (1991).

127. See, e.g., 42 AM. JuR. 2D InJunCtions § 41; Hadley v. Dep't of Corr., 840 N.E.2d 748, 756 (Ill. App. Ct. 2005).

128. See infra Part III.B.2.a.

129. See Apple, 869 F. Supp. 2d at 917 ("A related reason for withholding injunctive relief in this case is that it would be likely to impose costs on the alleged infringer disproportionate both to the benefits to it of having infringed and to the harm to the victim of infringement, and would thus be a windfall to the patentee and a form of punitive rather than compensatory damages imposed on 
implementer's need to use the patent is extremely high (compliance with the applicable standard turns on it), and, as discussed above, ${ }^{130}$ the harm to the patentee is more measurable than in the average patent case. ${ }^{131}$ This is akin to Justice Kennedy's observation in eBay Inc. $v$. MercExchange, L.L.C. that some non-practicing entities use "an injunction, and the potentially serious sanctions arising from its violation ... as a bargaining tool to charge exorbitant fees to companies that seek to buy licenses to practice the patent."132

But courts considering injunctive relief usually do not balance the parties' respective hardships where the defendant's wrongdoing was willful. ${ }^{133}$ Thus, this theory may explain what the courts mean when they say, as Judge Posner did, that injunctions might be appropriate where the implementer is unwilling to pay the RAND rate-the infringer in that case could not find shelter in a balance-of-harms analysis. ${ }^{134}$ This also might explain why some courts - including Judge Reyna's majority opinion in Apple v. Motorola - have left open the possibility of an injunction for implementers who act in bad faith in response to the patentee's licensing attempts. ${ }^{135}$ But, even if the court refuses to balance the harms because of the willfulness of the defendant's wrongdoing, this does not undermine the earlier point that legal remedies will generally be adequate to compensate a RAND-committed patentee for infringement of the encumbered patent, so that an injunction is not warranted based on past conduct. ${ }^{136}$

\footnotetext{
the infringer.").

130. See supra Part III.A.

131. One important consideration in injunctive relief is whether courts can fix damages "without imposing an unacceptably high risk of undercompensation" on the plaintiff. Anthony T. Kronman, Specific Performance, 45 U. CHI. L. REV. 351, 362 (1978). And what constitutes an "unacceptably" high risk of undercompensation will be measured against the harm that an injunction would cause the opposing party. See Van Wagner Adver. Corp. v. S \& M Enters., 492 N.E.2d 756, 760 (N.Y. 1986).

132. eBay Inc. v. MercExchange, L.L.C., 547 U.S. 388, 396 (2006) (Kennedy, J., concurring). Justice Kennedy related the use of an injunction threat as a bargaining chip to the adequacy of legal remedies and to the public interest:

When the patented invention is but a small component of the product the companies seek to produce and the threat of an injunction is employed simply for undue leverage in negotiations, legal damages may well be sufficient to compensate for the infringement and an injunction may not serve the public interest. Id. at 396-97.

133. James M. Fischer, What Hath eBay v. MercExchange Wrought?, 14 LEWIS \& CLARK L. REV. 555, 565 (2010).

134. See id.

135. See Apple Inc. v. Motorola, Inc., 757 F.3d 1286, 1332 (Fed. Cir. 2014), overruled by Williamson v. Citrix Online, LLC, 792 F.3d 1339 (Fed. Cir. 2015).

136. See Apple Inc. v. Samsung Elecs. Co. Ltd., 735 F.3d 1352, 1359 (Fed. Cir. 2013).
} 
c. Public Interest

The public interest includes considerations going both ways with respect to SEPs. ${ }^{137}$ Courts have often cited the public's interest in preserving patent integrity (favoring injunctions). The public also has a significant interest in the ability of SSOs to set workable and widelyadopted standards - the FTC has recognized the pro-competitive nature of this and its public benefit ${ }^{138}$ - and that ability could be hampered if injunctions were too readily available against standards implementers.

Another public interest concern is the potential for patentee opportunism that injunctions impose. ${ }^{139}$ While probably few would quibble with awarding injunctive relief against those implementers who willfully infringe with no intention of negotiating in good faith toward a RAND license (that is, those who would not get the benefit of a balance of harms analysis), such a standard creates a risk that innocent infringers will be mistaken for willful infringers. And, even if that is unlikely in practice, an implementer's perception of that risk would lead the riskaverse implementer to accept an above-RAND royalty rather than risk an injunction. Thus, any standard for the award of injunctive relief in RAND cases must assure innocent implementers that they will not face the threat of injunction. The standard that best fits that bill is the one that Judge Prost articulated in Apple v. Motorola: the removal of prelitigation conduct from the injunction analysis, ${ }^{140}$ leaving injunctions available only for post-litigation refusal to license.

Injunctive relief in the limited situation in which an implementer refuses to license at a court-adjudicated RAND rate (or otherwise cannot pay the rate) would not detrimentally impact the ability of SSOs to attract implementers. Implementers expect when they implement the standard to pay a RAND rate (as determined judicially if the parties cannot agree). And, certainly making injunctive relief available will not deter patentees from participating in SSOs - on the contrary, the absence of this relief

137. Apple, 757 F.3d at 1332 ("[T]he public has an interest in encouraging participation in standard-setting organizations but also in ensuring that SEPs are not overvalued.").

138. In re Certain Wireless Commc'n Devs., Portable Music \& Data Processing Devs., Computs. \& Components Thereof, ITC Inv. No. 337-TA-745, Third Party United States Fed. Trade Comm'ns Statement on the Pub. Interest, 2-4 (June 6, 2012), http://www.ftc.gov/sites/default/files/documents/advocacy_documents/ftc-comment-united-statesinternational-trade-commission-concerning-certain-wirelesscommunication/1206ftcwirelesscom.pdf.

139. See generally Realtek Semiconductor Corp. v. LSI Corp., 946 F. Supp. 2d 998, 1007 (N.D. Cal. 2013) ("[T] $[$ he pending threat of an exclusion order gives defendants inherent bargaining power in any RAND licensing negotiation that may now take place.").

140. Apple, 757 F.3d at 1343 (Prost, J., concurring in part and dissenting in part). 
might very well do so. Thus, the public's interest in thriving SSOs is not undercut by this very limited availability of injunctive relief. The public might also have an interest in the continuation of the defendant's business, as the district court held in $e B a y,{ }^{141}$ and as courts have held in many medical device cases. ${ }^{142}$ But, this analysis will necessarily be casespecific.

\section{d. Conclusion for Injunctive Relief}

Based on an analysis of these factors, we would generally expect injunctive relief to be unavailable in cases of standard-essential patents. The legal remedy of monetary damages will generally be adequate to compensate the patentee, who has already expressed a willingness to give up his right to exclude in exchange for monetary damages, and the balance of harms will tip strongly in favor of the implementer, at least in cases in which the harms are balanced. Moreover, the public interest cautions against the availability of injunctive relief in most cases. The availability of injunctions should be limited to those implementers who refuse to accept a license at a judicially determined RAND rate postlitigation, so that the patentee would be forced to file multiple periodic lawsuits in order to recover for the ongoing infringement. A corollary of this is that preliminary injunctions should be unavailable in SEP casesinfringement that occurs during the litigation can be captured in the initial damages award. ${ }^{143}$ For other protective interest concerns, we can turn to the remedy of enhanced damages.

\section{Enhanced Damages}

A second remedy that can serve the protective interest is enhanced damages. Under my analysis, injunctions can serve the first purpose of the protective interest in SEP cases - they can prevent post-litigation infringement by implementers who refuse to take a RAND license-but they cannot encourage infringers to negotiate in good faith for a RAND license pre-litigation if, as I suggest following Judge Prost's lead, pre-

141. MercExchange, L.L.C. v. eBay, Inc., 500 F. Supp. 2d 556, $586-87$ (E.D. Va. 2007).

142. Covidien Sales LLC v. Ethicon Endo-Surgery, Inc., No. 3:14-CV-917 (JCH), 2014 U.S. Dist. LEXIS 147060, at *36-37 (D. Conn. Oct. 15, 2014) (collecting cases).

143. Because the patentee will not have the preliminary injunction as "an adequate remedy for combating post-filing willful infringement," In re Seagate Tech., LLC, 497 F.3d 1360, 1374 (Fed. Cir. 2007) (en banc), enhanced damages for willful infringement during the litigation should be available to the patentee in appropriate cases. The standard for enhanced damages in SEP cases is discussed infra, in Part III.B.2. 
litigation conduct is removed from the injunction calculus. ${ }^{144}$ Consequently, if this aspect of the protective interest is to be served in SEP cases, it must be through enhanced damages. Fortunately, enhanced damages are well-suited for this purpose.

\section{a. The Preference for Enhanced Damages over Injunctions}

The patent laws allow courts to award enhanced damages (up to treble damages) against parties who willfully infringe. ${ }^{145}$ Enhanced damages are not intended to restore the patentee's rightful position-the patentee recovers more than necessary to make it whole ${ }^{146}$ - but, like the threat of injunctions, the specter of enhanced damages can protect the patentee's rightful position by incentivizing implementers to negotiate a license $e x$ ante rather than to infringe valid patents. ${ }^{147}$

Enhanced damages and injunctive relief can each incentivize wouldbe infringers to negotiate for a license and, consequently, have generally been lumped together in discussions by courts and commentators. But enhanced damages are preferable to injunctive relief to serve this second coercive aspect of the protective interest. Remember that the primary concern behind injunctive relief - and the concern driving the waiver view and the implied license view-is the potential for patentee opportunism. If even good-faith implementers feel that they could be

144. Judge Prost, in her partial dissent, emphasized this point noting that injunctions can "punish[]" implementers "for less than eager negotiations," but that enhanced damages can serve this same purpose. Apple, 757 F.3d at 1342 (Prost, J., concurring in part and dissenting in part).

145. 35 U.S.C. $\$ 284$ (2012). The Patent Act does not provide a standard for awarding enhanced damages - it simply permits the court to award damages up to three times compensatories. But judicial interpretations have long circumscribed the award to cases of willful infringement. See Seagate, 497 F.3d at 1368.

146. This is not an entirely uncontroversial assertion. See 7-20 CHISUM ON PATENTS § 20.03(4)(b)(iii), at 20-192. Part of the controversy stems from the absence of a scienter requirement in the patent statute. Id. But, as long as the "willfulness" requirement is judicially engrafted onto the statutory language, enhanced damages should be viewed as a punishment or deterrent. See id.

147. In addition, enhanced damages may fit under Professor Jimenez's discussion of the retributive interest, to the extent it exists in private civil law. See Jimenez, supra note 68, at 133840. To take the examples of the retributive interest cited by Professor Jimenez, see $i d$., the infringer with a good-faith claim of non-infringement, invalidity, or with a genuine disagreement about the RAND rate, resembles the innocent trespasser in Beck v. Northern Natural Gas Co., 170 F.3d 1018, 1021 (10th Cir. 1999), where the defendant leased underground storage for natural gas, and some of the gas leaked onto plaintiff's property. The Tenth Circuit concluded that fair rental value reflected the proper measure of restitution. Id. at 1024. Compare this case with Edwards v. Lee's Administrator, 96 S.W.2d 1028, 1028-29 (Ky. 1936), where Edwards discovered the entrance to the Great Onyx Cave on his property and turned the cave into a tourist attraction. Edwards knew that part of the tour included a portion of the cave under Lee's land. Id. at 1030. The court awarded restitution not based on that portion of the cave's fair rental value (the cave was inaccessible except through Edwards's entrance), but the profits Edwards derived from exploiting the portion of the cave under Lee's land. Id. at 1032-33. 
subject to an injunction, nullifying their investments in standard compliance and effectively driving them from the industry, good-faith but risk-averse implementers would end up accepting above-RAND licenses offered by opportunistic patentees. For several reasons, enhanced damages carry a lower risk of this result than injunctions do.

First, willfulness for enhanced damages must be proven by clear and convincing evidence, ${ }^{148}$ but there is no comparable heightened standard for the level of proof necessary for determining willfulness in deciding whether to balance the equities for injunctive relief ${ }^{149}$ - that is determined by a preponderance of the evidence. ${ }^{150}$ Second, enhanced damages are not binary; they can be awarded in any amount up to treble damages, ${ }^{151}$ depending in part on the certainty of the willfulness finding and the nature of the evidence. ${ }^{152}$ An injunction prohibiting the use of the patented invention, on the other hand, is either granted or denied-it is less obvious how it could be modified according to the particulars of the case. More importantly, in the event that a willfulness determination is in error, enhanced damages, while certainly a blow to the implementer's bottom line, do not effectively force the implementer out of the industry or allow the patentee to hold the implementer's business hostage in the way that a prohibitory injunction would. ${ }^{153}$

To the extent that enhanced damages and injunctive relief both serve the protective interest by encouraging good-faith license negotiations, there is no need to award them both, and enhanced damages are the preferable option. But, if enhanced damages are to encourage good-faith negotiation in the SEP context, the willfulness standard must be set in a way that avoids potential opportunism by either party-it must not risk imposing liability on the good-faith implementer but it must retain sufficient teeth to incentivize the conduct of opportunistic implementers.

\footnotetext{
148. Seagate, 497 F.3d at 1371.

149. See supra Part 3.B.1.b (explaining when the hardships to the parties are not balanced).

150. Brandt v. Burwell, 43 F. Supp. 3d 462, 483 (W.D. Pa. 2014).

151. Transclean Corp. v. Bridgewood Servs., Inc., 290 F.3d 1364, 1377-78 (Fed. Cir. 2002).

152. See CHISUM, supra note 146, § 20.03(4)(b)(vi), at 20-460.110 nn.368.366-68, 20-460.136 n.366.432 and accompanying text.

153. Enhanced damages should nevertheless eliminate opportunistic conduct on the part of the implementer, at least as long as the specter of enhanced damages makes the risk of infringement outweigh the expected profit of infringement, the implementer has incentive to take a license. At the very least, the threat of enhanced damages should cause the implementer to negotiate in good faith once it is approached by the patentee.
} 
b. Knowledge of the Patent

Willful infringement requires at least objective recklessness, ${ }^{154}$ meaning that there must have been an "objectively high likelihood" both that the patent was valid and that the defendant's actions infringed the patent. ${ }^{155}$ To be willful, the patent infringement must have been "either known or so obvious that it should have been known to the accused infringer." the patent at issue. ${ }^{157}$ Willfulness hinges on the totality of the circumstances, and no one factor is controlling. ${ }^{158}$

With respect to the knowledge requirement, an implementer does not have sufficient knowledge of the patent merely because the patentee declared the patent to be standard-essential. Although one might suggest that the implementer knows of the patent by virtue of the patentee's declaration that the patent is an SEP, this suggestion would impose too high a burden on standard implementers. More importantly, it is not the standard imposed by patent law, which requires actual notice rather than constructive notice. ${ }^{159}$ Some standards may contain thousands of declared-SEPs, ${ }^{160}$ and the SSO does not usually inquire into the validity of the patent or the patentee's claims that its patent reads on the standard. For most SSOs, anyone can declare a patent to be an SEP, subject to agreeing to the RAND commitment, and questions about whether the patent is valid or infringed by standard implementation are left for later determination among implementers and patentees. ${ }^{161}$ And in some cases, patentees offer blanket assurances that they will license any SEPs in their

154. Stryker Corp. v. Zimmer, Inc., 782 F.3d 649, 660-61 (Fed. Cir. 2014); Seagate, 497 F.3d at 1371.

155. Uniloc USA, Inc. v. Microsoft Corp., 632 F.3d 1292, 1310 (Fed. Cir. 2011).

156. Id.

157. State Indus., Inc. v. A.O. Smith Corp., 751 F.2d 1226, 1235 (Fed. Cir. 1985); Deckers Outdoor Corp. v. J.C. Penney Co., 45 F. Supp. 3d 1181, 1188 (C.D. Cal. 2014) ("Actual knowledge - not constructive knowledge - is the criterion.").

158. Seagate, 497 F.3d at 1369.

159. Imonex Servs., Inc. v. W.H. Munzprufer Dietmar Trenner GMBH, 408 F.3d 1374, 1377 (Fed. Cir. 2005) (a pre-Seagate case, holding that "[w]illful infringement in this case hinges on when the defendants had actual knowledge of Imonex's patent rights, and their actions after that time").

160. See Lemley, supra note 3, at 151; see also Ericsson, Inc. v. D-Link Sys., Inc., 773 F.3d 1201, 1234 (Fed. Cir. 2014) ("The mere fact that thousands of patents are declared to be essential to a standard does not mean that a standard-compliant company will necessarily have to pay a royalty to each SEP holder.").

161. See Anne Layne-Farrar et al., Pricing Patents for Licensing in Standard-Setting Organizations: Making Sense of FRAND Commitments, 74 ANTITRUST L.J. 671, 683 (2007); Certain Wireless Devs. With 3G and/or 4G Capabilities and Components Thereof, Inv. No. 337-TA-868, USITC at 111-12 (June 13, 2014). 
entire patent portfolios at RAND rates, ${ }^{162}$ which does not place the implementers on notice with respect to any specific patent, particularly if the patentee's portfolio is far-reaching.

Thus, for a finding of willful infringement, it is not sufficient for the patentee to simply point to the SEP declaration and suggest that the implementer knew of the patent; the implementer must have some more specific notice of the patent that is claimed to be infringed. But there is a related question: once the implementer has notice of the patent, what are the implementer's obligations with respect to seeking a license? ${ }^{163}$

\section{c. The Implementer's Recklessness}

Until 2008, the Federal Circuit had held that an infringer had a duty to exercise due care in avoiding infringement. ${ }^{164}$ In In re Seagate, the en banc Federal Circuit removed the presumption of willfulness that arose from an infringer's failure to exercise due care to avoid infringement. ${ }^{165}$ Now, willfulness turns primarily on whether the infringer was objectively reckless with respect to infringement. ${ }^{166}$ This means that "the infringer was aware of the asserted patent, but nonetheless 'acted despite an objectively high likelihood that its actions constituted infringement of a valid patent." 167 The subjective prong of the Seagate inquiry means that "the infringer knew or should have known of this objectively high risk." 168 Infringement is likely to be willful if the implementer (1) has specific notice (beyond the SEP declaration) of the patent, including the applicability to the standard; (2) lacks a substantial basis for arguing noninfringement; and (3) lacks a substantial basis for arguing invalidity or unenforceability. ${ }^{169}$ Again, there is little here that differs from a standard

162. Gregory K. Leonard \& Mario A. Lopez, Determining RAND Royalty Rates for StandardEssential Patents, 29-FALl ANTITRUST 86, 90 (2014).

163. This question is related because it applies only when the implementer's notice of the patent comes from a source other than direct notice from the patentee. When the notice comes directly from the patentee, it will almost always be accompanied by a demand letter/licensing offer.

164. In re Seagate Tech., LLC, 497 F.3d 1360, 1368-69 (Fed. Cir. 2007) (en banc).

165. See Spectralytics, Inc. v. Cordis Corp., 649 F.3d 1336, 1349 (Fed. Cir. 2011).

166. Seagate, 497 F.3d at 1371.

167. i4i Ltd. P'ship v. Microsoft Corp., 598 F.3d 831, 860 (Fed. Cir. 2010).

168. Id.

169. See, e.g., Seagate, 497 F.3d at 1374 (noting that a substantial question about invalidity or noninfringement may avoid a charge of willfulness); Black \& Decker, Inc. v. Robert Bosch Tool Corp., 260 F. App'x 284, 291 (Fed. Cir. 2008) (nonprecedential); see also Minks v. Polaris Indus., Inc., No. 6:05-cv-1894-Orl-31KRS, 2007 WL 788418, at *1 (M.D. Fla. 2007), aff'd in part, vacated in part, remanded in part, 546 F.3d 1364, 1380-81 (Fed. Cir. 2008) (affirming award of enhanced damages on plain error review where infringer did not investigate infringement despite "several warning flags" that gave it notice of the infringement); Dan L. Burk \& Mark A. Lemley, Quantum Patent Mechanics, 9 LEWIS \& CLARK L. REV. 29, 55 (2005). 
patent case outside of the RAND context. There is, however, a difference in the obligations of the parties once the implementer is alerted to the claimed infringement.

In most cases, if the infringer continues to infringe after being alerted to the patent and to the claimed infringement, and if the infringer lacks any objectively reasonable defense, willfulness will be found. ${ }^{170}$ In fact, "[w] $[\mathrm{were}$ a potential infringer unsuccessfully seeks a license from the patentee, the potential infringer may have a higher duty of due care to avoid infringement." 171 In other words, outside of the standard-essential patent context, if the infringer unsuccessfully attempts to procure a license to a valid patent that it infringes, it may well be subject to enhanced damages for any products it makes or sells thereafter. But in the RAND context, the implementer knows that the patentee has committed to license the patent at a RAND rate, and it should not be forced to quit manufacturing or selling the standard-compliant product as the result of a good-faith disagreement as to the licensing rate. Indeed, some have argued that the RAND commitment fulfills its purpose by enabling the parties to delay negotiation. ${ }^{172}$ If the implementer were forced to quit making or selling its product during the negotiation period, then the patentee could opportunistically compel an above-RAND license rate by intentionally protracting the negotiations. Thus, willfulness should not be found where the implementer continues to make or sell the infringing products while it negotiates (or litigates) in good faith for a RAND-rate license. ${ }^{173}$ Similarly, if the patentee withdraws from the negotiations, the implementer remains free to continue manufacturing the infringing product without subjecting itself to enhanced damages, as long as the implementer demonstrated a

170. See sources cited supra note 169.

171. Robert A. Matthews, JR., 4 Annotated Patent Digest § 31:20 (2005); Spindelfabrik Suessen-Schurr Stahlecker \& Grill GmbH v. Schubert \& Salzer Maschinenfabrik Aktiengesellschaft, 829 F.2d 1075, 1084 (Fed. Cir. 1987) ("Schubert attempted unsuccessfully to obtain a license ... [This] supports a conclusion that Schubert was explicitly aware of the possibility of infringement. Under those circumstances, Schubert must be held to a high degree of caution ..."). The language used here is that of the pre-Seagate standard.

172. Lichtman, supra note 28, at 1041.

173. There are two potential legal avenues by which to reach this conclusion. The first is that willfulness "measures the infringing behavior... against an objective standard of reasonable commercial behavior in the same circumstances." Hoechst Celanese Corp. v. BP Chems. Ltd., 78 F.3d 1575, 1583 (Fed. Cir. 1996). Because it is commercially reasonable for an implementer who knows of the patentee's RAND-commitment to continue to produce its products under the RANDcommitment assurances, the implementer's conduct would not be willful. But, even if the implementer's conduct could be considered "willful infringement" under the Seagate standard, Seagate, 497 F.3d at 1360, enhanced damages do not follow inexorably from a willfulness finding, but instead rest on the totality of the circumstances, including the interests of justice and the infringer's culpability. See Matthews, supra note 171, at $\S 31: 16$. 
willingness to engage in good faith negotiations. ${ }^{174}$

In essence, and quite unlike ordinary patent infringement, good-faith licensing negotiations provide a safe harbor against enhanced damages in cases involving a RAND-encumbered SEP, even if those negotiations break down. We can find a helpful analogue in the insurance context, in which mere failure to pay the amount due under the insurance contract will not subject the insurer to punitive damages - the insurer must refuse to pay in bad faith. ${ }^{175}$ In concluding that the standard of proof for a claim of bad faith should be by clear and convincing evidence, one court noted that a "preponderance of the evidence" standard would pressure insurers to forgo even good-faith defenses to payment out of fear of being stuck with punitive damages. ${ }^{176}$ Such a rule "would make claims nondisputable [and] would result in prohibitive social costs" by allowing opportunism on the part of the insured. ${ }^{177}$

This same concern - the desire to promote license negotiations between the parties without threatening the good-faith implementer with enhanced damages if the negotiations fail-bespeaks caution in establishing the standard of willfulness applicable in the RAND context. Willfulness determinations, while possible in the context of a RANDencumbered SEP, should be more rare than in traditional patent litigation, ${ }^{178}$ because the RAND commitment creates an additional hurdle to a finding of willfulness. Specifically, the implementer must, in addition to having knowledge of the patent and no objectively reasonable defenses, nevertheless act with the intent not to procure a RAND license. Judge Prost made a similar point in her partial dissent in Apple $v$. Motorola, in which she argued that, "if a trial court believes that an infringer previously engaged in bad faith negotiations, it is entitled to increase the damages." 179 Under this view, a good-faith disagreement

174. Alternatively, the implementer could sue the patentee for specific performance of its RAND obligations, as some implementers have done. See, e.g., Microsoft Corp. v. Motorola, Inc., No. C10-1823JLR, 2013 WL 2111217, at*1 (W.D. Wash. Apr. 25, 2013); Realtek Semiconductor Corp. v. LSI Corp., 946 F. Supp. 2d 998, 1001 (N.D. Cal. 2013).

175. See Travelers Indem. Co. v. Armstrong, 442 N.E.2d 349, 363 (Ind. 1982).

176. Id.

177. Id. ("A rule that would permit an award of punitive damages upon inferences permissibly drawn from evidence... which may be nothing more than a refusal to pay the amount demanded and subsequently found to be owing - injects such risks into refusing and defending against questionable claims as to render them, in essence, non-disputable. The public interest cannot be served by any policy that deters resort to the courts for the determination of bona fide commercial disputes.").

178. Between August 2007 and July 2010, willfulness was found in approximately $37.2 \%$ of patent infringement cases that went to trial. Christopher B. Seaman, Willful Patent Infringement and Enhanced Damages After In re Seagate: An Empirical Study, 97 Iowa L. REV. 417, 441 (2012).

179. Apple Inc. v. Motorola, Inc., 757 F.3d 1286, 1342 (Fed. Cir. 2014) (Prost, J., dissenting in 
about the measure of RAND terms would preclude a finding of willfulness, but the implementer's refusal to negotiate, if itself in bad faith, would not. ${ }^{180}$

\section{Mandatory Injunctions: Ongoing Royalties}

As discussed above, prohibitory injunctions serve the protective interest through the direct injunctive command-proscribing further injunction post-judgment-and through the threat of injunction that incentivizes infringers to seek a license. The second method is also served by enhanced damages, which are preferable to injunctive relief in SEP cases. ${ }^{181}$ But there is also another remedy that can accomplish the first task of prohibiting post-judgment infringement. This other remedy is the ongoing royalty - an order that essentially permits the infringer's continued infringement of the patent, but orders the payment of a set royalty for each act of infringement. ${ }^{182}$

\section{a. Authority to Order an Ongoing Royalty}

The ongoing royalty is a relatively recent development in patent law, ${ }^{183}$ becoming prominent after the Supreme Court's eBay decision and a district court's 2006 decision in Paice LLC v. Toyota Motor Corp. ${ }^{184}$ Courts are usually unclear about the authority under which they award ongoing royalties. Patent law provides for federal courts to "grant injunctions in accordance with the principles of equity to prevent the violation of any right secured by patent, on such terms as the court deems reasonable," 185 language that the Federal Circuit has held restricts the

part), overruled by Williamson v. Citrix Online, LLC, 792 F.3d 1339 (Fed. Cir. 2015). Judge Prost stated that the trial judge could increase damages "to account for any harm to the patentee as a result of that behavior," but the above analysis would permit enhanced damages, not necessarily to account for harm to the patentee, but to serve the protective interest. Id.

180. This does not mean that a refusal to negotiate is necessarily in bad faith. For example, when the implementer seeks judicial recourse as to the RAND rate without negotiation because it reasonably believes that negotiation would be fruitless, the implementer is not likely acting in bad faith. See Microsoft, 2013 WL 2111217, at *1-2 (in which Microsoft sued Motorola for breach of its RAND commitment without countering Motorola's excessive initial offer).

181. See supra Part III.B.2.a.

182. Apple Inc. v. Samsung Elecs. Co. Ltd., No. 12-CV-00630-LHK, 2014 WL 6687122, at*2 (N.D. Cal. Nov. 25, 2014).

183. See Foster v. Am. Mach. \& Foundry Co., 492 F.2d 1317, 1324 (2d Cir. 1974) (denying request for injunctive relief and ordering compulsory license).

184. Paice LLC v. Toyota Motor Corp., No. 2:04-CV-211-DF, 2006 WL 2385139 (E.D. Tex. Aug. 16, 2006), aff'd in part, vacated in part, 504 F.3d 1293, 1314-15 (Fed. Cir. 2007).

185. 35 U.S.C. $§ 283$ (2012). 
"scope of activities that may be enjoined."186 Although that court has insisted that ongoing royalties are awarded "in lieu of an injunction," "187 the Federal Circuit has also indicated that an ongoing royalty is a form of injunction. ${ }^{188}$ In a decision remanding a case for the district court to determine an ongoing royalty, the Federal Circuit did not directly refer to the ongoing royalty as an injunction, but, in a footnote, it referred to "[a]n injunction delineating the terms of the compulsory license." 189 Even though the Federal Circuit has avoided explicitly describing an ongoing royalty as injunctive, ${ }^{190}$ district courts have determined that the authority to award an ongoing royalty stems from the court's power to enter injunctive relief. ${ }^{191}$

This conclusion raises an interesting issue, because courts that have awarded ongoing royalties have first almost uniformly denied prohibitory injunctions on the grounds that, among other things, the legal remedies are adequate. ${ }^{192}$ The finding of an adequate legal remedy should theoretically foreclose all injunctive relief under $e B a y,{ }^{193}$ including the ongoing license. ${ }^{194}$ But, as discussed above, serial lawsuits are generally considered an inadequate legal remedy. ${ }^{195}$ Thus, it would seem that the real desideratum in these ongoing royalty cases is not the adequacy vel non of the legal remedy but is instead that the balance of harms and the public interest favor an ongoing royalty as opposed to a prohibitory injunction.

186. Paice, 504 F.3d at 1314.

187. Id. at $1314-15$.

188. Id. ("The more difficult question ... is whether an order permitting use of a patented invention in exchange for a royalty is properly characterized as preventing the violation of the rights secured by the patent.").

189. Innogenetics, N.V. v. Abbott Labs., 512 F.3d 1363, 1381 n.9 (Fed. Cir. 2008).

190. See Paice, 504 F.3d at 1315-16 (recognizing the ongoing royalty as an equitable remedy on which a jury trial is not required, but refraining from referring to the remedy as an injunction).

191. Mondis Tech. Ltd. v. Chimei Innolux Corp., No. 2:11-CV-378-JRG, 2012 WL 1554645, at *6-7 (E.D. Tex. Apr. 30, 2012).

192. See, e.g., Paice LLC v. Toyota Motor Corp., No. 2:04-CV-211-DF, 2006 WL 2385139, at *5 (E.D. Tex. Aug. 16, 2006) (denying injunction), aff'd in part, vacated in part, 504 F.3d 1293 (Fed. Cir. 2007); Paice LLC v. Toyota Motor Corp., 609 F. Supp. 2d 620, 639 (E.D. Tex. 2009) (granting ongoing royalty); Affinity Labs of Tex., LLC v. BMW N. Am., LLC, 783 F. Supp. 2d 891, 896 (E.D. Tex. 2011) (noting denial of injunctive relief and granting ongoing royalty); Creative Internet Adver. Corp. v. Yahoo! Inc., 674 F. Supp. 2d 847, 852 (E.D. Tex. 2009) (concluding that patent has an adequate legal remedy, and then awarding ongoing royalty).

193. eBay Inc. v. MercExchange, LLC, 547 U.S. 388, 391-94 (2006).

194. But see Apple, Inc. v. Samsung Elecs. Co. Ltd., No. 12-CV-00630-LHK, 2014 WL 6687122 , at $* 8$ (N.D. Cal. Nov. 25, 2014) ("Samsung cites no cases that apply the four-factor permanent injunction test to ongoing royalties. Indeed, it is unclear how the Court could apply the second $e$ Bay factor- 'that remedies available at law, such as monetary damages, are inadequate to compensate for that injury' - to an award of ongoing royalties.").

195. See supra note 131. 
b. Determining an Ongoing Royalty in SEP Cases

An ongoing royalty will be unnecessary in most RAND-encumbered SEP cases because the implementer will likely take a license once the RAND rate is judicially determined, and the patentee will likely grant a license. If the implementer refuses to take a license once the RAND rate has been determined, there is no obvious reason not to grant prohibitory injunctive relief instead of choosing to award an ongoing royalty. But the ongoing royalty can nevertheless provide an alternative to a prohibitory injunction, and it may prove particularly useful in a few specific situations. First, courts may order an ongoing royalty when the patentee refuses to accept a license at the judicially determined RAND rate - this would, in essence, use an ongoing royalty as a form of compulsory license. ${ }^{196}$ The ongoing royalty would also prove useful in cases in which the implementer wants to appeal the calculation of the RAND rate, and the patentee refuses to enter into a license agreement that preserves the implementer's right to appeal. ${ }^{197}$ In that situation, the court may consider an ongoing royalty so that the implementer is not excluded during appeal and the patentee does not have to initiate a later suit to collect the royalties. ${ }^{198}$ Finally, an ongoing royalty could potentially prove useful if the parties are unable to reach an agreement, even post-judgment, with regard to other license terms besides the royalty rate, such as cross-licensing terms, forum-selection clauses, or the like.

Outside of the SEP context, ongoing royalties are sometimes awarded at a higher rate than the "reasonable royalties" that were awarded as damages in the litigation ${ }^{199}$ in part because the continuing post-verdict infringement is necessarily willful, ${ }^{200}$ in part because the patentee is forced to give up its right to exclude against its will; ${ }^{201}$ and in

196. This could be done through a claim for specific performance of the RAND commitment, discussed infra Part IV.C. Alternatively, the patentee's refusal to enter into such a license could be considered a breach of its RAND commitment, the damages of which would encompass any litigation fees expended by the implementer in future infringement litigation filed by the patentee.

197. See, e.g., Realtek Semiconductor Corp. v. LSI Corp., 946 F. Supp. 2d 998, $1004-05$ (N.D. Cal. 2013).

198. If the implementer is insolvent or otherwise unable to pay the ongoing royalty, the patentee should be able to obtain a prohibitory injunction, because an ongoing royalty would leave the patentee short of its rightful position.

199. Creative Internet Adver. Corp. v. Yahoo! Inc., 674 F. Supp. 2d 847, 861 (E.D. Tex. 2009); Mondis Tech. Ltd. v. Chimei InnoLux Corp., 822 F. Supp. 2d 639, 652-53 (E.D. Tex. 2011), aff'd sub nom., 530 F. App'x 959 (Fed. Cir. 2013); Affinity Labs of Tex., LLC v. BMW N. Am., LLC, 783 F. Supp. 2d 891, 903-04 (E.D. Tex. 2011).

200. Mondis, 822 F. Supp. 2d at 649; Affinity Labs, 783 F. Supp. 2d at 899.

201. Paice LLC v. Toyota Motor Corp., 609 F. Supp. 2d 620, 624 (E.D. Tex. 2009) ("[T]he 
part because the parties' bargaining positions and circumstances may have changed. ${ }^{202}$ Whatever the merits of that solution in other cases, those rationales are wholly unpersuasive in RAND cases. By entering into a RAND commitment, the patentee has already voluntarily relinquished its right to exclude, and the ongoing royalty merely enforces the patentee's RAND obligation. Relatedly, it is difficult to describe the continuing use of the patent as willful infringement if the implementer pays the RAND rate - the very rate at which the patentee is obligated to license the patent if it were upholding its RAND obligations. And, while changes in bargaining positions may affect royalty calculation outside of the RAND context, ${ }^{203}$ those changes should not affect the RAND rate, which, as discussed below, should almost always be calculated as of a time prior to the incorporation of the patent into the standard. ${ }^{204}$

Another common rationale for a heightened ongoing royalty rate is that the ongoing royalty "has a significant impact on [the patentee's] ability to license its technology to others and effectively precludes an exclusive licensing arrangement." 205 This too is a non-issue in a RAND case because the RAND commitment itself precludes exclusive licensing, and an additional compulsory license leaves unchanged the patentee's ability (and obligation) to license its technology to others. As the Paice court said in determining an ongoing royalty rate, the question

question instead becomes: what amount of money would reasonably compensate a patentee for giving up his right to exclude yet allow an ongoing willful infringer to make a reasonable profit?").

202. ActiveVideo Networks, Inc. v. Verizon Commc'ns, Inc., 694 F.3d 1312, 1343 (Fed. Cir. 2012); Apple, Inc. v. Samsung Elecs. Co., No. 12-CV-00630-LHK, 2014 WL 6687122, at*15 (N.D. Cal. Nov. 25, 2014).

203. Outside of the RAND context, the reasonable royalty does not necessarily include "changes in the market between the date of the hypothetical negotiation and the date of trial," but the ongoing royalty is calculated based on all of the facts known at the time of its calculation. Affinity Labs, 783 F. Supp. 2d at 898 n.6; see Mondis, 822 F. Supp. 2d at 647, ("[T]he Court focuses on any new evidence that was not before the jury and additionally any changed circumstances ... between a hypothetical negotiation that occurred in 2005 (which the jury determined) and a hypothetical negotiation that would occur in 2011 after the judgment (which this Court is determining).").

204. See infra Part IV.B.

205. Paice, 609 F. Supp. 2d at 630. Another oft-cited reason for a heightened ongoing royalty is the "parties' changed legal status"- that the patent has been adjudicated valid and infringed. Id. at 628. But this reasoning seems insufficient, because validity and infringement are assumed in calculating the reasonable royalty. See Mark A. Lemley, The Ongoing Confusion Over Ongoing Royalties, 76 MO. L. REV. 695, 704-05 (2011). Perhaps this simply reflects the courts' beliefs that, despite this formal requirement for the reasonable royalty calculation, factfinders nevertheless impose a patent strength discount. Indeed, such a discount might be all but inevitable. Existing licenses are considered the best evidence of a reasonable royalty, but existing licenses-whether procured under the threat of litigation or not-will reflect a discount for the parties' assessment of patent strength (that is, validity and infringement). See Layne S. Keele, Res" Q'"ing Patent Infringement Damages After ResQNet: The Dangers of Litigation Licenses as Evidence of a Reasonable Royalty, 20 TEX. INTELL. PROP. L.J. 181, 205-07 (2012). 
is "what amount of money would reasonably compensate a patentee for giving up his right to exclude." 206 In the case of a RAND-encumbered SEP, we know that the patentee has already expressed a willingness to give up its right to exclude in exchange for a RAND royalty and, by the time the court considers whether to award an ongoing royalty, it will have already determined the RAND rate. ${ }^{207}$ Thus, the answer to the Paice court's question in such cases is, "the judicially determined RAND rate." But that raises a separate question: How should a court determine the RAND rate?

\section{OTHER ISSUES REGARDING RAND OBLIGATIONS}

The above discussion suggests that damages awards at the RAND rate will restore the patentee to its rightful position. ${ }^{208}$ But determining the kind of remedy appropriate in these cases is only the first step. The second step is determining how to properly calculate a RAND royalty.

\section{A. Judicial Determination of the RAND Rate}

The reasonable royalty is typically calculated using the GeorgiaPacific factors - a list of fifteen factors, of which the most important is the royalty that would have been agreed upon if the patentee and infringer had negotiated a royalty. ${ }^{209}$ The reasonable royalty calculation in its most common form undertakes a hypothetical negotiation between the patentee and infringer immediately before the infringing conduct began. ${ }^{210}$ Courts tasked with determining a RAND rate have also used this hypothetical negotiation as a starting point for the RAND calculation. ${ }^{211}$

Only a few courts so far have discussed the RAND rate

206. Paice, 609 F. Supp. 2d at 624.

207. The RAND rate will be a question of fact for the jury, unless the parties waive the right to a jury determination. See In re Innovatio IP Ventures, LLC Patent Litig., No. 11C9308, 2013 WL 5593609 , at $* 2$ (N.D. Ill. Oct. 3, 2013). Because the ongoing royalty is equitable, it will be set by the court. Paice LLC v. Toyota Motor Corp., 504 F.3d 1293, 1316 (Fed. Cir. 2007).

208. See supra Part III.A.

209. Ga.-Pac. Corp. v. U.S. Plywood Corp., 318 F. Supp. 1116, 1120 (S.D.N.Y. 1970). Judge Posner poked fun at the "non-exhaustive" fifteen factor list from Georgia-Pacific. Apple, Inc. v. Motorola, Inc., 869 F. Supp. 2d 901, 910-11 (N.D. Ill. 2012), aff'd in part, rev'd in part and remanded, 757 F.3d 1286 (Fed. Cir. 2014).

210. Keele, supra note 205, at 187-88.

211. See Ericsson, Inc. v. D-Link Sys., Inc., 773 F.3d 1201, 1234 (Fed. Cir. 2014); Microsoft Corp. v. Motorola, Inc., No. C10-1823JLR, 2013 WL 2111217, at *16-20 (W.D. Wash. Apr. 25, 2013); Innovatio, 2013 WL 5593609, at *5-6. 
determination in depth. ${ }^{212}$ This is a difficult task, as demonstrated by Judge Robart's 207-page opinion in Microsoft v. Motorola, ${ }^{213}$ later affirmed by the Ninth Circuit. ${ }^{214}$ Most of the time, determination of the RAND rate will be a question for the jury, ${ }^{215}$ although the parties agreed to a bench trial in Microsoft ${ }^{216}$ and Innovatio. ${ }^{217}$ In Microsoft, Judge Robart recognized that an actual negotiation might produce nonmonetary consideration, such as cross-licenses, but he looked only to monetary compensation in determining a RAND. ${ }^{218}$

Judge Robart outlined some "basic principles" for assessing RAND terms. The methodology adopted should mitigate patent holdup risks and royalty stacking risks, and it should award "the economic value of [the] patented technology itself, apart from the value associated with incorporation of the patented technology into the standard."219 The Federal Circuit recently echoed that sentiment, noting, "[j] ust as we apportion damages for a patent that covers a small part of a device, we must also apportion damages for SEPs that cover only a small part of a standard."220 Judge Robart rejected Microsoft's proposed approach, which would have determined the RAND rate by "calculating the incremental value of the technology compared to the alternatives that could have been written into the standard." ${ }^{\text {"21 }}$ Instead, he adopted a modified reasonable royalty approach involving a hypothetical negotiation between the patentee and implementer, with the negotiation taking place prior to the standard's adoption. ${ }^{222}$ Of course, the incremental value of the technology compared with available alternatives would tightly constrain the amount that would be agreed to by the negotiating parties, so that the incremental value of the patent is a key

212. Ericsson, 773 F.3d at 1229 ("To our knowledge, only three other courts have considered the issue of appropriate RAND royalty rates - all district courts.").

213. See Microsoft, 2013 WL 2111217, at*101.

214. Microsoft Corp. v. Motorola, Inc., 795 F.3d 1024 (9th Cir. 2015).

215. See Ericsson, 773 F.3d at 1225.

216. Microsoft Corp. v. Motorola, Inc., No. C10-1823JLR, 2012 WL 4827743, at *4 (W.D. Wash. Oct. 10, 2012).

217. Innovatio, 2013 WL 5593609 , at $* 2$.

218. Judge Robart had no need to look at non-monetary consideration, because the pleadings sought only monetary consideration. Microsoft, $2013 \mathrm{WL} 2111217$, at *3 n.3.

219. Id. at *12.

220. Ericsson, 773 F.3d at $1232-33$.

221. Microsoft, 2013 WL 2111217, at *13. He rejected this approach in part because it would be difficult to determine in some cases where alternative technology would have required a much different standard, which may or may not be able to accomplish the same end result. Id.

222. Id. at *18-19. The Federal Circuit recently declined to comment on "whether shifting the timing of the hypothetical negotiation is either appropriate or necessary" in RAND cases. Ericsson, 773 F.3d at 1239 n.10. See also Michel, supra note 33, at 904 (arguing that the hypothetical negotiation should occur "when the decision to use the technology [in the standard] was made"). 
consideration of the hypothetical negotiators. ${ }^{223}$ For this reason, the Federal Circuit has held that, particularly in the SEP context, "the patent holder should only be compensated for the approximate incremental benefit derived from his invention." 224

This does not mean that the RAND royalty will necessarily be capped by the incremental value provided by the patented technology over the next-best alternative. This is so because the alternatives may have costs as well. For example, imagine that Patent X's technology can transcode video with a 3-second delay, and Patent Y (the alternative considered by the SSO) can transcode video with a 5-second delay, and software in the public domain can transcode video with a 15 -second delay. If we imagine that the value of transcoding video in 3 seconds instead of 5 seconds is $\$ 1$, this does not mean that the value of Patent $X$ in the standard is $\$ 1$, because, absent Patent X, the SSO would have had to either use the public domain software (with a 15-second delay) or incorporate Patent $\mathrm{Y}$ at some cost-let's say \$1.50. Thus, the incremental value added by Patent $\mathrm{X}$ is the difference between 3 -second transcoding and 15-second transcoding, or the difference between 3second transcoding and 5-second transcoding $(\$ 1)$ plus the value of Patent Y over the public domain software $(\$ 1.50$ in this example, for a total of $\$ 2.50)$.

Judge Robart set out the factors that should influence the hypothetical negotiation. He started with the Georgia-Pacific factors used to calculate a reasonable royalty in patent infringement cases. ${ }^{225}$ As Judge Robart and the Federal Circuit have recognized, some of those factors, such as the licensor's desire to maintain its patent monopoly or antipathy toward licensing a competitor, would not apply in the RAND context, where the patentee has committed to license all comers without discriminating. ${ }^{226}$ With respect to the remaining factors, Judge Robart noted the importance of identifying the value added to the implementer's products by the patented technology rather than the value resulting from the implementer's use of the standard. ${ }^{227}$

With regard to the twelfth factor-the typical royalty for this invention or comparable inventions-Judge Robart said that only

\footnotetext{
223. Indeed, one of the Georgia-Pacific factors (factor 9) relates to determining a reasonable royalty relates to the advantages of the patented invention over other available technology. Microsoft, 2013 WL 2111217, at *92.

224. Ericsson, 773 F.3d at 1233.

225. Microsoft, 2013 WL 2111217 , at *17.

226. Ericsson, 773 F.3d at 1230-31; Microsoft, 2013 WL 2111217, at *18.

227. Microsoft, 2013 WL 2111217 , at *18.
} 
RAND-committed licenses would matter; "licensing fees for non-RAND committed patents customary in a business industry cannot form the basis for comparison." 228 But it is not obvious why this should be so. Again, the primary concern driving RAND obligations is to avoid poststandard patent holdup in which the patentee insists on recovering some of the value of the standard. But a license agreement for a non-standardessential patent covering similar technology would not incorporate any value derived from standardization, and thus would seem to be probative evidence of a RAND license. ${ }^{229}$ Although such a license might be an imperfect analogy, that does not render it useless in the endeavor of a RAND calculation. ${ }^{230}$

Georgia-Pacific factor fifteen is the most important-it is the basis of the hypothetical negotiation and asks what amount a willing licensor and licensee would have agreed upon at the time the infringement began. In this case, Judge Robart said that the parties would "consider the RAND commitment and its purposes," and "[i]n trying to reach an agreement, the SEP owner would have been obligated to license its SEPs on RAND terms, which necessarily must abide by the purpose of the RAND commitment of widespread adoption of the standard through avoidance of holdup and stacking."231 (Royalty stacking involves worries that, if the standard incorporates many patents, the price of standard compliance may be too high. ${ }^{232}$ ) Judge Robart said that, to address stacking concerns, the parties would consider "other SEP holders and the royalty rate that each of these patent holders might seek from the implementer based [on] the importance of these other patents to the standard and to the implementer's products. $" 233$

There is no indication in the Microsoft opinion that royalty stacking had occurred with the standards involved, and, consequently, it was likely not appropriate for the court to use stacking concerns to effectively

228. Id. at *19; see also In re Innovatio IP Ventures, LLC Patent Litig., No. 11C9308, 2013 WL 5593609 , at *33 (N.D. Ill. Oct. 3, 2013) ("[T]here is no evidence that the Symbol-Proxim jury verdict was based on RAND considerations."); id. at *36 ("The court does not take a position on the question of whether non-RAND licenses can ever be useful in determining a RAND rate.").

229. Unless, of course, the patent was part of the standard, but the patentee had managed to avoid encumbering its patent with a RAND commitment. In that case, the license will include exactly what the RAND-rate seeks to exclude: standardization value.

230. Ericsson, 773 F.3d at 1227 ("Prior licenses ... are almost never perfectly analogous to the infringement action."); see also Keele, supra note 205, at 204-06.

231. Microsoft, 2013 WL 2111217 , at $* 20$.

232. Innovatio, $2013 \mathrm{WL} 5593609$, at $* 9$.

233. Microsoft, 2013 WL 2111217, at *86. In other words, Judge Robart's methodology appears to require a RAND license evaluation for all SEPs. 
cap the RAND rate. $^{234}$ The Federal Circuit recently held that a jury considering a reasonable royalty in a RAND case should not be instructed about royalty-stacking concerns unless there is "evidence on the record of ... royalty stacking in relation to both the RAND commitment at issue and the specific technology referenced therein."235 The Innovatio court considered royalty stacking in a more limited way than Judge Robart - only as a check to ensure "that the asserted patents are not overvalued compared to the technological contribution they make to the standard." 236 This seems sensible because, just as standard incorporation should not increase the royalty paid over the value of the patented technology (meaning that patentees should not be able to command a higher price through patent holdup), it should not generally decrease the royalty below that value. As Judge Robart acknowledged in Microsoft, the RAND rate should hinge "on the economic value of [the] patented technology itself, apart from the value associated with incorporation of the patented technology into the standard."237

Judge Robart then described the standards (802.11 and H.264) and patents at issue. After examining the patents and their role in the standards, Judge Robart looked to the importance of the patents to the implementer (in this case, Microsoft). In determining a RAND rate, Judge Robart properly ignored evidence about the value of standard compliance to Microsoft. $^{238} \mathrm{He}$ also suggested that, even though the SSO's intellectual property rights policies may include patents that are essential to optional parts of the standard within the definition of SEPs, those patents "have a lower value than patents that are essential to the required portions." 239

After examining the importance of each of Motorola's patents to the standards at issue (that is, their value over other available technology at the time the standards were adopted) and the importance of each of Motorola's patents to Microsoft (that is, the prevalence of Microsoft's use of the patented systems or processes in various Microsoft products), Judge Robart looked to other licenses of the patents in suit and of other SEPs for assistance in determining the RAND rate. Using these other licenses as comparables, Judge Robart set a RAND royalty rate.

\footnotetext{
234. See id. at $* 100$ (opining that "stacking concerns from the perspective of the implementer govern the upper bound of RAND").

235. Ericsson, 773 F.3d at 1234-35.

236. Innovatio, 2013 WL 5593609, at $* 10$. Judge Robart later applied a similar analysis. Microsoft, 2013 WL 2111217, at *73.

237. Microsoft, 2013 WL 2111217 , at $* 12$.

238. Id. at *44 (describing testimony).

239. Id. at $* 51$.
} 
Some patentees with SEPs had created patent pools to license their patents to implementers of the standards in question, and Judge Robart relied heavily on these pools in determining the RAND rate. ${ }^{240} \mathrm{He}$ looked at various rates discussed in setting patent pool rates and apportioned those rates to Motorola based on its patent portfolio. He used the pool rates as the best indicator because Motorola had not shown that its patents were more valuable than the average patent in the pool, and his own analysis of the patents at issue indicated that the patents provided little value to the standard and to Microsoft. ${ }^{241}$

One aspect of Judge Robart's method of using the patent pools appears to have inflated the royalty amounts that he assigned. He concluded that pool membership had value outside of the royalties received-value from "having full access to the immense technology included in the MPEG LA H.264 patent pool"-because Microsoft paid into the pool twice as much as it received from the pool. ${ }^{242} \mathrm{He}$ determined that "Microsoft views membership in the MPEG LA H.264 patent pool as providing a value of at least twice as much as it receives in royalty rates," and he figured the RAND rate by tripling his calculation of what Motorola would have received had it joined the pool. ${ }^{243}$ The reasoning for this conclusion is unclear. Presumably, Microsoft pays into the pool to license the patents of other pool members. ${ }^{244}$ This is not a function of membership in the pool, but of paying for patent licenses to use the standard-something that members and non-members alike will do. The amount that the member pays into the pool is not a benefit of membership in the pool but is, instead, the cost of licensing other pool members' patents. ${ }^{245}$ If Judge Robart's initial determination was correct

\footnotetext{
240. Id. at $* 82-86$.

241. Id. at *85-86.

242. Id. at $* 84$.

243. Id. at *84-85, 100 .

244. See Microsoft Corp. v. Motorola, Inc., 795 F.3d 1024, 1043 (9th Cir. 2015) (“Typically, pool members contributing their patents to the pool also become licensees of the pool's patent package.”).

245. Consider it this way. If Motorola had joined the pool, it would have received a royalty (as Judge Robart found) of 0.185 cents per unit. It might have paid some amount (twice that, perhaps, although we don't know) into the pool in order to join the pool and to license the other technology in the pool for its own products. But, if it is going to implement the standard, it has to license that technology, and it can do so by paying the pool whether it is a pool member or not. If pool members get a discount on the licensing rate from the rate paid by non-members, that discount would be a benefit of membership in the pool. But it does not follow from the fact that Microsoft paid into the pool approximately twice what it received from the pool in royalties that pool membership is worth a total of three times the royalty received from the pool, so that the royalty rate Motorola would have received from the pool should be tripled. As the Ninth Circuit noted in rejecting Motorola's complaint on this issue, however, Judge Robart's conclusion regarding the pool licenses was favorable to Motorola. See id. at 1043.
} 
that the pool royalty rate serves as a general indicator of a RAND-rate (and there is no reason to think that it could not, subject to tweaking for individuation according to the particular patents at issue), Judge Robart was right to examine the full value received from the pool by pool members, if any, in addition to the cash value of the royalties received. ${ }^{246}$ But it is not clear that payments into the pool quantify benefits of pool membership, as opposed to merely reflecting payments for licensing the pool patents.

The key question in a RAND calculation is the value of the patented technology, and in general damages contexts, courts determine value by asking what price would be agreed to by a willing buyer and seller. ${ }^{247}$ Thus, on the whole, it makes sense to determine the RAND rate with reference to a hypothetical negotiation incorporated from the reasonable royalty determination in other patent cases, and the Federal Circuit has approved this methodology. ${ }^{248}$

\section{B. The Impact of Litigation Risk on the RAND Rate}

I argue above that enhanced damages should be available in rare cases against implementers who infringe RAND-encumbered SEPs in order to incentivize implementers to negotiate in good faith. ${ }^{249}$ But there is another point, relevant to the remedial interests, that impacts the parties' incentives to negotiate toward a license: the RAND royalty calculated in litigation should be higher than a pre-litigation RAND royalty, at least where the court's calculation follows a determination that the patent is valid and infringed, because pre-litigation negotiations take place amid litigation risk. ${ }^{250}$ This is true outside of the SEP context as well; in the hypothetical negotiation between the patentee and infringer that occurs immediately prior to the start of infringement, the parties presume the patent is valid, enforceable, and infringed. ${ }^{251}$ In other words, the hypothetical negotiation does not include a litigationrisk discount.

\footnotetext{
246. See id.

247. Factory Mut. Ins. Co. v. Alon USA L.P., 705 F.3d 518, 521 (5th Cir. 2013).

248. See Ericsson, Inc. v. D-Link Sys., Inc., 773 F.3d 1201, 1234 (Fed. Cir. 2014).

249. See supra Part III.B.2.

250. In re Innovatio IP Ventures, LLC Patent Litig., No. 11C9308, 2013 WL 5593609, at *7 (N.D. Ill. Oct. 3, 2013) ("Nonetheless, by the time the damages phase of an infringement suit arrives, the court has determined infringement and validity, thus foreclosing the hypothetical negotiator from benefiting from any uncertainty as to future court rulings."); see also Realtek Semiconductor Corp. v. LSI Corp., No. C-12-03451-RMW, 2014 WL 46997, at *1 (N.D. Cal. Jan. 6, 2014).

251. IP Innovation L.L.C. v. Red Hat, Inc., 705 F. Supp. 2d 687, 689 (E.D. Tex. 2010).
} 
Unlike the hypothetical negotiation, real-world pre-litigation negotiations occur amid litigation risk. Because of this, the implementer should be able to license the patent pre-litigation for less than what the court would determine to be the RAND rate after it has found infringement and validity. ${ }^{252}$ Thus, the risk-averse implementer would have some incentive to negotiate for a license pre-litigation. But litigation risk has an even greater impact on the patentee's negotiating position than it does on the implementer's because of the unilateral nature of non-mutual collateral estoppel. If the patent is held invalid, the patent becomes unenforceable against any future standards implementers, ${ }^{253}$ whereas, if the patent is determined to be valid against one implementer, any future standards implementers may nevertheless challenge the validity of the patent. ${ }^{254}$ Consequently, the patentee must multiply the downside risk of an invalidity determination over the total number of implementers, but it does not get the equivalent upside from a validity determination.

Imagine, for example, that both parties estimate a $90 \%$ chance of patent validity, and that the RAND rate amounts to $\$ 100,000$. Leaving the probability of infringement and expected attorneys' fees to the side, the infringer should settle for $\$ 90,000$ or less. But the infringer can insist on much less because of the patentee's litigation risk. Assume the patentee expects to enforce the patent against another implementer later. In calculating its expected value from litigation, the patentee must include the chance that an invalidity determination will eliminate enforcement against the second implementer. The patentee's expected value includes a $90 \%$ chance of $\$ 100,000$ (from this litigation) plus an $81 \%$ of another $\$ 100,000$ (from the second implementer), ${ }^{255}$ for a total expected value of $\$ 171,000$. If he settles this litigation, he eliminates one of the opportunities for invalidity, and his chances of getting the $\$ 100,000$ in the second litigation increase to $90 \%$. This means that he should settle the first case for $\$ 81,000$ or more, because his expected value from both cases would then equal or exceed his expected value

252. Michel, supra note 33, at 908 (discussing impact of litigation risk on the ongoing royalty rate).

253. Pharmacia \& Upjohn Co. v. Mylan Pharms., Inc., 170 F.3d 1373, 1379 (Fed. Cir. 1999).

254. Cf. Mark A. Lemley \& A. Douglas Melamed, Missing the Forest for the Trolls, 113 ColuM. L. REV. 2117, 2163 (2013) (discussing, in the context of patent trolls, the desire to settle early rather than risk an invalidity determination).

255. The second litigation's expected value is the product of the probable RAND rate award $(\$ 100,000)$ and the odds that the patentee will be able to enforce that patent $(0.9 \times 0.9$, because there are two opportunities for the patent to be held invalid). For purposes of the illustration, I am treating the odds of an invalidity finding as fixed across all suits at 0.9 -in reality, those odds might change. 
from litigation of both cases $(\$ 171,000)$. If the patentee expects to enforce the patent against three implementers, his expected value from litigation is $\$ 244,000,{ }^{256}$ and he should settle the first case for anything more than $\$ 72,900 .^{257}$ If the patentee hopes to sue a total of ten implementers, he will settle the first litigation for $\$ 34,867.85$ rather than risk an invalidity determination. ${ }^{258}$

The patentee's settlement calculus must account for the litigation risk not only with respect to the implementer involved in this case, but also with respect to all potential implementers against whom it hopes to enforce the patent. This may make only a small difference in many patent cases, where the patentee may not expect to enforce the patent against many parties, but, in SEP cases, the patentee expects there to be many standard implementers. Consequently, we would expect negotiated settlements to fall well below the RAND rate-yet another reason that enhanced damages are important to serve the protective interest. $^{259}$

\section{Specific Performance of the Patentee's RAND Commitment}

Where a patentee breaches its RAND commitment by refusing to negotiate toward a RAND-rate license, ${ }^{260}$ an implementer may have several remedies. One such remedy might be a breach of contract suit, at least where the patentee refuses to negotiate toward a RAND license in good faith and instead seeks injunctive relief against the implementer. ${ }^{261}$

256. This is the sum of the expected value of the first litigation $(\$ 90,000)$, the expected value of the second litigation $(\$ 81,000)$, and the expected value of the third litigation $(\$ 72,900)$.

257. If the patentee settles the first case, his odds of recovering in the second and third cases increase to $90 \%$ and $81 \%$, respectively.

258. The settlement value for a given case in these circumstances is 0.9 to the power of the number of expected lawsuits multiplied by the likely RAND rate. Thus, if the patentee expects ten infringers, the settlement value of the first case is $0.9^{\wedge} 10 * \$ 100,000$, or $\$ 34,867.85$.

259. See supra note 28 and accompanying text (commentators arguing against availability of enhanced damages); supra Part III.B.2 (explaining the role of enhanced damages in serving the protective interest).

260. Realtek Semiconductor Corp. v. LSI Corp., 946 F. Supp. 2d 998, 1008 (N.D. Cal. 2013) (holding that patentee breached RAND commitment by seeking injunctive relief without first offering a license); but see Apple, Inc. v. Motorola Mobility, Inc., 11-CV-178-BBC, 2012 WL 5943791, at *1 (W.D. Wis. Nov. 28, 2012) (concluding that patentee did not breach RAND commitment by requesting injunctive relief).

261. In Microsoft Corp. v. Motorola, Inc., No. C10-1823JLR, 2013 WL 6000017, at*1-2 (W.D. Wash. Nov. 12, 2013), aff'd, 795 F.3d 1024 (9th Cir. 2015), Microsoft claimed that Motorola breached its RAND commitment by, among other things, negotiating in bad faith before seeking injunctive relief against Microsoft. Microsoft recovered as damages from Motorola the attorneys' fees it expended in contesting Motorola's injunction actions. Microsoft Corp. v. Motorola, Inc., 795 F.3d 1024, 1047-48 (9th Cir. 2015). 
Or an implementer might seek specific performance-a court ordered license at a RAND rate, calculated to include a litigation risk discount (because, in a specific-performance setting, the calculation takes place without a determination of validity and infringement). ${ }^{262}$ Alternatively, we might say that the implementer does not need a license-it can simply wait for the patentee to sue, and then use the RAND commitment to limit the patentee's damages. But specific performance may be valuable to the implementer for several reasons. First, under the RAND commitment, the implementer is entitled to avoid the litigation risks by taking a RAND license, and leaving the implementer with the specter of litigation hanging over it and its attendant risks threatens its ability to operate going forward. Second, as explained above, the RAND rate should be calculated differently after a determination of infringement and validity, so that specific performance may be more valuable to the implementer than awaiting a determination of infringement damages. In addition, the suit for specific performance would insulate the implementer from enhanced damages concerns.

Some patentees have argued that the RAND commitment is too vague to be specifically enforced. ${ }^{263}$ The courts, however, have rejected that argument. ${ }^{264}$ If the RAND commitment is enforceable, a court must be able to determine the RAND rate. ${ }^{265}$ And, once we acknowledge that courts are capable of determining the RAND rate, specific performance

262. In Microsoft, the court simply incorporated uncertainty in the RAND range calculation, acknowledging that, where the patentee and the implementer had different reasonable views of infringement, these different views would lead to a different RAND rate calculation. See, e.g., Microsoft Corp. v. Motorola, Inc., No. C10-1823JLR, 2013 WL 2111217, at *60 (W.D. Wash. Apr. $25,2013)$. To the extent that the judge discounted the RAND rate for patent strength uncertainty, that rate should not later be used for any damages award on an infringement claim because the RAND rate awarded for infringement should not reflect a litigation risk discount. See supra Part IV.A. Also, Judge Robart appeared skeptical about the validity of one of the patents at issue. Microsoft, 2013 WL 2111217, at *32 ("Moreover, Microsoft presented convincing evidence that the '980 Patent disclosed prediction of motion using the same three blocks that the prior art used for progressive video.... Accordingly, the court concludes that it would have been intuitive for a person of ordinary skill to use the same blocks for interlaced video that were already known to work for progressive video." (citations omitted)).

263. See, e.g., Apple, Inc. v. Motorola Mobility, Inc., No. 11-CV-178-BBC, 2011 WL 7324582, at $* 9$ (W.D. Wis. June 7, 2011).

264. See, e.g., ESS Tech., Inc. v. PC-Tel, Inc., No. C-99-20292-RMW, 1999 WL 33520483, at *4 (N.D. Cal. Nov. 4, 1999) ("[T] he court could easily determine what a fair and non-discriminatory contract would be.”); Apple, Inc. v. Motorola Mobility, Inc., No. 11-CV-178-BBC, 2012 WL 5416941, at *3-4 (W.D. Wis. Oct. 29, 2012) ("I conclude that specific performance may be an appropriate remedy under the circumstances of this case. In fact, it may be the only appropriate remedy.").

265. See Realtek Semiconductor, Corp. v. LSI Corp., No. C-12-3451-RMW, 2014 WL 2738226, at *6 (N.D. Cal. June 6, 2014) (declaring RAND commitment obligations after a jury determination of the RAND rate). 
is easily implemented, at least where the RAND commitment does not include significant exceptions or caveats. Earlier cases in the sales context - generally cases in which one party had an option to purchase or lease property at a "reasonable" price-offer precedent for specific performance in reasonable-price cases. ${ }^{266}$

Courts have, however, rejected complaints by implementers who seek specific performance or a RAND declaration where the implementer refuses to commit to take a license at the declared rate. ${ }^{267}$ In such a case, it appears that the implementer intends to use the rate as a ceiling from which to bargain downward, rather than to use it to get that to which the implementer is entitled (that is, a RAND-rate license). Courts tend to avoid serving as pawns in negotiating leverage, and the refusal to issue a declaratory judgment or specific performance in a case like this is almost certainly a reasonable exercise of their discretion. If courts choose to declare the RAND rate and the implementer refuses to commit to a license, then both injunctive relief and enhanced damages for post-declaration infringement may be available. ${ }^{268}$

\section{CONCLUSION}

The RAND commitment has two purposes that are in tension with one another: to avoid patent holdup and to ensure a reasonable return to patentees, in turn encouraging innovator participation in the standardsetting process. In order for the RAND commitment to navigate the tension of these dual purposes, courts must take great care in SEP cases to properly implement the available remedies. These remedies have been the source of considerable academic and judicial disagreement. If injunctive relief or enhanced damages are too easily awarded, they would undermine the holdup-avoiding purpose of the RAND commitment. On

266. See, e.g., City Stores Co. v. Ammerman, 266 F. Supp. 766, 771-72 (D.D.C. 1967), aff'd, 394 F.2d 950 (D.C. Cir. 1968) (specifically enforcing agreement for option to lease property on terms at least as favorable as lessor had given other tenants); Morris v. Ballard, 16 F.2d 175, 176 (D.C. Cir. 1926) (permitting specific performance of agreement to purchase property for a certain price with "terms to be agreed upon"); Shayeb v. Holland, 73 N.E.2d 731, 733 (Mass. 1947) (permitting specific performance of option to purchase land that was silent as to price, which the court interpreted to mean a "fair and reasonable price"); see also Chaney v. Schneider, 206 P.2d 669, 670-71 (Cal. Ct. App. 1949).

267. See Apple Inc. v. Motorola Mobility, Inc., No. 11-CV-178-BBC, 2012 WL 7989412, at*3 (W.D. Wis. Nov. 8, 2012). There are a number of sales cases in which the parties had agreed that one party would have the option to purchase goods or property from the other at a reasonable price, but in all of those cases, the party bringing suit sought to enforce the option (in other words, the party with the option had affirmatively exercised it). See, e.g., Fischer Imaging Corp. v. Gen. Elec. Co., 187 F.3d 1165, 1167 (10th Cir. 1999); Shayeb, 73 N.E.2d at 732.

268. See supra Part III.B. 
the other hand, if these remedies are unavailable in any case, the leverage shifts to the implementer, who can insist on a below-RAND license rate without incurring any risk from willful patent infringement.

Under the contract view of the RAND commitment, which parallels open-price contracts that have long been enforceable in the Article 2 context, the RAND commitment will generally limit damages for the unintentional infringement of RAND-encumbered patents to a RAND royalty. This royalty should be calculated in much the same way that a reasonable royalty is calculated in other patent contexts, with some minor tweaks that I discuss in this Article. This RAND award will restore the injured patentee to its rightful position.

The protective and coercive interests present more of a challenge in the RAND context. In this Article, I argue that enhanced damages should be available in appropriate cases - that is, those in which the standard implementer knew of the patent, continued to infringe despite the absence of a substantial argument of non-infringement or invalidity, and acted in bad faith in response to license negotiation efforts. Although injunctive relief can serve the protective interest in the same way that enhanced damages do, enhanced damages are better positioned to accommodate the purposes of the RAND commitment. Preliminary injunctions should not be available in cases of RAND-encumbered patents, and permanent prohibitory injunctions should be rare, usually limited to the implementer's post-litigation refusal to take a license at a judicially determined RAND rate. Also, an ongoing royalty award may be useful in some situations, but it should be awarded at the same RAND rate that the court calculated for its damages award.

The RAND commitment can effectively encourage standard creation, an essential component of an increasingly interconnected society, but it requires circumspection in the remedies available against infringers of RAND-encumbered patents. As detailed in this Article, a meticulous application of patent law's existing remedial framework enables the RAND commitment to serve the restorative and protective interests - and, correspondingly, the coercive interest - without the need for categorical prohibitions on injunctive relief or enhanced damages. 